\title{
Did Political Constraints Bind during Transition? Evidence from Czech Elections 1990-2002 ${ }^{\nabla}$
}

\author{
Orla Doyle + and Patrick Paul Walsh ‡
}

† Geary Institute, University College Dublin, Dublin 4, Ireland

‡IIIS and Department of Economics, Trinity College Dublin, Dublin 2, Ireland

"Historical events mostly imitate one another without any talent but it seems to me that in Bohemia, history staged an unprecedented experiment” Kundera (1987)

\footnotetext{
${ }^{\nabla}$ Corresponding author: orla.doyle@ucd.ie. Tel: (+353 1) 716 4637. Fax: (+353 1) 716 1108. Address: Geary Institute, University College Dublin, Belfield, Dublin 4, Ireland. This paper benefited from many helpful comments and suggestions from participants in seminars at ZEI in Bonn, and the CEPR Annual Transition Economics Summer Workshop for Young Academics in Slovenia. Our thanks also to Jan Fidrmuc, John Jackson, Chris Minns and Chris Anderson for many helpful comments and suggestions.
} 


\title{
Did Political Constraints Bind during Transition? \\ Evidence from Czech Elections 1990-2002
}

\begin{abstract}
Many theoretical models of transition are driven by the assumption that economic decision making is subject to political constraints. In this paper we empirically test whether the winners and losers of economic reform determined voting behaviour in the first five national elections in the Czech Republic. We propose that voters, taking stock of endowments from the planning era, could predict whether they would become "winners" or "losers" of transition. Using survey data we measure the percentage of individuals by region who were "afraid" and "not afraid" of economic reform in 1990. We define the former as potential "winners" who should vote for pro-reform parties, while latter are potential "losers" who should support left-wing parties. Using national election results and regional economic indicators, we demonstrate that there is persistence in support for pro-reform and communist parties driven by prospective voting based on initial conditions in 1990. As a result, we show that regional unemployment rates in 2002 are good predictors of regional voting patterns in 1990.
\end{abstract}

Keywords: Political Constraints, Prospective Economic Voting, Initial Conditions. JEL Classifications: D72, E24, E61 


\section{Introduction}

The term political constraint is used to describe economic decision making under the constraint that decisions have to be largely acceptable to the general population. This constraint is central to the theoretical literature on the economics of transition, for example Dewatripont and Roland (1995). These models assume that voters, with rational expectations, taking stock of endowments from the planning era, can predict, under some uncertainty, whether they would become "winners" or "losers" of the reform process. Any successful reform sequence has to satisfy political constraints. ${ }^{1}$ This assumes not only do economic conditions affect voting outcomes but, in the language of political scientists, economic voting should be prospective in nature, both of which are major debates in the field.

Theoretical and empirical work on the economics of voting in Western democracies constitutes a vast area of both the political science and economics literatures. Studies applying such economic voting models to post-communist countries, however, have been quite limited to date. Using economic models to explain voting patterns is particularly appropriate for the former communist societies, where economic considerations are paramount and can substantially affect vote choice due to low party identification. Unlike established democracies where voters have been socialised within their political and economic system, voters in transition countries have no prior experience of competitive political parties, ${ }^{2}$ free elections and indeed a market economy. Therefore, analysing economic voting in a system undergoing vast structural changes and subsequent economic and political turbulence enables the investigation of whether voting is influenced by past, present or future economic conditions. In general, the retrospective voting hypothesis receives most attention in the economic voting literature. The popularity of the retrospective 
approach stems from the difficulty in distinguishing retrospective voting from prospective voting. As rational voters form expectations based on current and past economic conditions, the boundaries between the two approaches are often blurred and can be hard to empirically separate out. ${ }^{3}$ Elections in emerging democracies such as the Czech Republic, however, enable a better test of the retrospective/prospective debate. ${ }^{4}$

The first free election in a post-communist society represented a natural break in history, whereby one-party communist rule was replaced by a multi-party democratic system and voters' choice sets were expanded to include a variety of new political parties. As the majority of these parties did not exist, or lay dormant during the previous four decades (apart from the former-ruling Communist Party), voters could not rely on cues from the past in order to form judgments about the future. Therefore, unlike electoral decisions in established democracies, voters in the Czech Republic in 1990 could not evaluate political parties based on their previous economic performance in government.

The most comprehensive survey of voting studies in the post-communist world was carried out by Tucker (2002). He created a database of 101 articles on elections and voting in post-communist countries, which were published between 1990 and 2000. While Tucker identifies ten economic voting studies in his database (Pacek, 1994; Gibson and Cielecka, 1995; Bell, 1997; Fidrmuc, 2000a, 2000b; Tucker, 2000a, 2001; Colton, 1996a; Mason and Sidorenko-Stephenson, 1997; Powers and Cox, 1997; and Harper, 2000), none explicitly examine the Czech Republic. In addition, while Fidrmuc, Pacek, and Tucker go a long way in explaining Czech voting patterns in a multi-country context, given the cross-sectional nature of these studies they do not investigate the initial determinants of voting patterns. These studies suggest that the 
traditional retrospective hypothesis may not be an appropriate strategy in a postcommunist context; however, explicit tests for the presence of prospective voting are not performed. From a theoretical viewpoint Stokes (2001) also argues that the retrospective voting hypothesis may not be an appropriate strategy in emerging democracies which are undergoing radical economic transformation and proposes three alternative prospectively orientated hypotheses. This paper, therefore, takes advantage of the unique experiences initiated by the fall Communism, to provide the first comprehensive test of the retrospective/prospective debate by analysing voting behaviour in the Czech Republic throughout its post-communist transition.

We test whether the winners and losers of economic reform actually determined voting behaviour using evidence from the first five national elections in the Czech Republic. We propose that voters at the regional level, taking stock of endowments from the planning era, could predict whether they would become "winners" or "losers" of the transition process. Using survey data we measure the percentage of individuals, by region, who were "afraid" and "not afraid” of economic reforms in 1990. We define the former as potential "winners" who should vote for pro-reform parties, while the latter are potential "losers" who should support left-wing parties. Using national election results, we demonstrate that there is persistence in support for pro-reform and communist parties driven by prospective voting on initial conditions. As a result, we show that regional unemployment rates in 2002 are good predictors of regional voting patterns in 1990. We provide empirical evidence that political constraints actually bind during transition.

Classic economic voting models typically find that election results vary in line with conventional economic indicators, at both national and regional levels. This study, on the other hand, demonstrates that trends in voting patterns at a regional level 
in the Czech Republic emerged during the first post-communist election, when standard economic cues, such as the unemployment and inflation rates and GDP growth were limited, or were not highly informative with respect to future economic conditions, as the economic reform process had not yet begun. An examination of the 1990 election reveals substantial regional variation in support for pro-reform and leftwing parties, while the unemployment rate was very low across all regions and only varied between $0.09 \%$ and $1.91 \%$ at the time of the election. The failure of such contemporary economic variables to explain regional voting patterns in the first election suggests that other factors determined these initial voting patterns. This paper proposes that this unobservable phenomenon was the region's inheritance from the communist period, embodied in the endowments of physical and human capital present in the region, its trade orientation ${ }^{5}$ and its sectoral employment distribution. Furthermore, despite the limited regional variation in regards unemployment and wage rates during the early 1990's, regions throughout the Czech Republic greatly differed in regards their initial endowments. This study demonstrates that these endowments subsequently influenced expectations about the outcomes of the reform process, regional election results and economic developments during the transition period.

It should be noted that the majority of post-communist economic voting studies do not analyse the founding election in the post-communist state, as it is argued that this election is a referendum on communism, and hence economic voting models should not apply. This paper demonstrates that while contemporary regional economic conditions, which were an outcome of the reform process, influenced voting decisions in later elections (see Fidrmuc, 2000a, 2000b and Tucker, 2001, 2004), these voting patterns were largely pre-determined in 1990. 
The paper proceeds as follows: section 2 describes Czech voting patterns and highlight trends in the data across regions and time. Section 3 introduces the data and methodology employed in the analysis. Section 4 presents the results of the two-part empirical analysis. Sub-section 4.1 presents the estimates of three models of five Czech elections from 1990-2002, and sub-section 4.2 investigates the prospectiveness of the 1990 election. Finally, section 5 discusses the overall findings of the study.

\section{Voting Patterns in the Czech Republic}

The Czech Republic is the only East European country to experience continuous democracy during the inter-war period. Czechoslovakia's had four free elections during the First Republic (1920, 1925, 1929 and 1935) and a semi-free election in 1946. Since 1990, the Czech Republic has held five parliamentary elections to the Chamber of Deputies (lower house). While the first three elections (1990, 1992 and 1996) resulted in the re-election of the pro-reform right-wing government, the 1998 and 2002 election saw the centre-left Social-Democrats form a minority government.

The main obstacle to overcome when analysing post-communist elections is the high degree of fragmentation across the political parties over time. To overcome this fragmentation inherent to the Czech political system, parties in this analysis are divided into four main categories - Pro-Reform, Centre-Left, Communist and Others. Table 1 displays the list of individual parties that constitute each group for each election year. The categorisation has been based on the perceived political orientation of the parties before the elections, rather than the actual policies pursued by the parties ex-post. Mateju and Rehakova (1996) find that the positions of Czech parties 
remained relatively stable throughout the post-communist period, and that it was the voters, not the political parties, that moved within the left-right spectrum.

Table 2 displays the evolution of support for the four main party groups at a regional level. Overall, voting patterns in the Czech Republic are characterised by two phenomena: 1) persistence in Pro-Reform and Communist voting and 2) volatility within the Centre-Left and smaller parties. First, Table 2 shows that support for ProReform parties at a regional level is relatively constant across each election period. The Pro-Reform group incorporates right-wing parties that advocate full speed reforms in order to instigate a competitive market economy. In 1990 the Pro-Reform group encompasses Civic Forum (OF), an umbrella movement consisting of smaller pro-reform and anti-communist parties, and the Christian and Democratic UnionCzechoslovak Peoples Party (KDU-CSL). After the 1990 election Civic Forum disintegrated into three parties, Civic Democratic Party (ODS), Civic Democratic Alliance (ODA) and Civic Movement (OH). The ODS is the most successful proreform party in the Czech Republic, winning both the 1992 and 1996 elections, with its vote share only declining slightly in the 1998 and 2002 elections. This party, therefore, constitutes the majority of the Pro-Reform group in every election year. The pro-reform Christian Democratic Union (KDU-CSL), which has been consistently successful in winning seats in every election since 1990, maintaining their vote share of between $8 \%-9 \%$ in every election, is also included in the Pro-Reform group. The 1998 Pro-Reform group also includes Freedom Union (US) which broke away from ODS due to internal disputes, and subsequently gained $8.6 \%$ of the vote in the 1998 election. Finally, the 2002 Pro-Reform grouping also includes the Coalition Party. The Coalition was formed in February 2000 and originally consisted of the Christian Democratic Union, Democratic Union (DEU), Freedom Union and Civic Democratic 
Alliance. However, the “Quad Coalition” collapsed in 2001 and only US-DEU (which merged into a single party) and KDU-CSL remained.

While the Pro-Reform group initially lost support after the first election, which can be attributed to the disintegration of Civic Forum, their vote share has remained quite constant, averaging $44.1 \%$ in $1992,41.71 \%$ in $1996,42.92 \%$ in 1998 , and receiving its lowest vote share of $36.72 \%$ in 2000 . In addition, while its support has declined across all regions its relative support at a regional level has remained highly persistent. Regions that voted for a pro-reform party in 1990 continued to do so in all subsequent elections. There is a high correlation between election-to-election proreform voting patterns from 1990 to 2002 (e.g. the correlation between 1990 and 2002 Pro-Reform voting is 0.6.).

A similar, albeit stronger, pattern is found for support for the Communist group. The second major grouping, the Communists, constitutes the main ideological opponent to the above pro-reform parties. The Communist Party of Bohemia and Moravia (KSCM) is a descendent of the former Communist Party of Czechoslovakia and is classified as a socialist party that believes in strong state control of the economy. Unlike its counterparts in other post-communist countries ${ }^{6}$, it failed to reconstruct itself and shed its communist image. This strategy, however, has proved successful, as the Communist group has maintained its vote share of $11-19 \%$ for all elections and its popularity is increasing, as demonstrated in the latest election.

A major assumption predominant in studies of post-communist elections is that voting patterns are highly volatile, however as seen above, regional voting patterns for both the Pro-Reform and Communist group have remained persistent across all five elections. Czech electoral volatility, therefore, has mainly come from the evolution of the Centre-Left. ${ }^{7}$ As seen in Table 1 the Centre-Left group mainly encompasses Czech 
Social Democratic Party (CSSD) which failed to pass the threshold for representation in the 1990 election, however its vote share has since escalated. The CSSD promotes a more gradualist approach to economic reforms, and aspires to become a standard European social democratic party. This party was the first to offer a credible alternative to governments dominated by the Pro-Reform parties. The CSSD saw its vote share rise dramatically in the 1996 election from $14.59 \%$ to $26.99 \%$ and subsequently won the 1998 and 2002 elections. The rise in support for the Centre-Left can be attributed to vote swings from anti-reform parties, and also from smaller parties that dissolved after the 1990 and 1992 election. Narwa (1997) in an examination of electoral volatility in the Czech Republic between the 1992 and 1996 elections, found, using ecological regressions, that the CSSD attracted voters from the LB (Left Block), the SPR-RSC (Nationalists) and smaller parties. This shift in votes from more extreme parties, which promote radical and anti-reform policies, to the centre-left which promotes gradualist economic policies, reflects both voters' experience with the reform process and increased voter sophistication. As the outcomes of the major reform packages were realised, the voters' economic positions changed. As voters gained experience with the electoral process ${ }^{8}$ they recognised that votes cast for small or extreme parties were essentially wasted, as typically these parties do not gain representation in parliament. Therefore, as transition progresses, voters became more politically aware and realised that in order for their interests to be represented in the parliament, they had to change their voting behaviour and cast votes for parties with a credible prospect of gaining representation.

Overall the Czech electoral data highlights two important observations. First, there is persistence in regional support for both Pro-Reform and Communist parties. This suggests that during the first post-communist election, voters did not rely on 
contemporary economic indicators when forming their vote choices, but instead formed predictions as to the future success of their region, based on the initial endowments their region inherited from the communist regime. Secondly, the electoral data also shows there is high level of volatility within the left block, such that there are distinct swings towards the centre-left as transition continues. The evolution of the Centre-Left provided the Pro-Reform group with real political competition and led to the crystallisation of the Czech political scene. These issues are examined further in the following sections.

\section{Data and Methodology}

The empirical analysis is based on national electoral data ${ }^{9}$ taken at the level of regions (okres) for the first five elections to the Chamber of Deputies (lower house) in the Czech Republic. In total 76 regions are analysed for all elections. ${ }^{10}$ While regional election data is not utilised a great deal in the literature, with the exceptions of Fidrmuc (2000a, 2000b) and Tucker (2001), it serves as an intermediary between the macro and micro approaches to economic voting. Using regional data assumes voting behaviour is determined by economic conditions in the voters' immediate surroundings, which have a more direct and tangible effect on the voters' preferences than the national economic environment. Therefore, one may expect that regional level data will reveal relationships that do not emerge from national data. For example, while there was a general pro-market euphoria at a national level in the early transition period, and hence high support for pro-reform parties, an analysis of electoral data reveals that this euphoria was not universally shared, such that individual regions displayed considerable heterogeneity in their electoral preferences. 
The dependent variable is the proportion of votes, $V_{i j}$, that each party category $j$ receives from voters in region $i$. Therefore, the data display two specific properties that need to be taken into account in the analysis ${ }^{11}$ : the individual observations lie between 0 and 1, and the proportion of votes received by all parties sum to one. The majority of voting studies to date have been estimated using ordinary least squares (OLS). ${ }^{12}$ Yet, as argued by Jackson (2001) and Tomz, Tucker and Wittenberg (2002), OLS is inappropriate for analyses of elections in multiparty systems, as it does not satisfy either of the above mentioned restrictions. In particular, OLS can result in predicted vote shares that are negative or exceed 1 (that is, 100\%).

All regressions in this analysis are estimated using the Seemingly Unrelated Regression (SUR) model that takes account of the adding-up constraint characteristic of election data. SUR is a special case of generalized least squares, which estimates a set of equations with cross-equation constraints imposed. Specifically, it allows for the possibility that the residuals are correlated across parties. Therefore, if one party has a large positive residual, the others will have small and some negative residuals for that observation. Estimating a set of seemingly unrelated regressions jointly as a system yields more efficient estimates than estimating them separately, especially as the correlation among the errors rises and the correlation among the independent variables falls (Greene, 2000). SUR is also particularly efficient when the independent variables differ from one equation to the next. Overall SUR is more appropriate and no less efficient or convenient than estimating individual OLS equations for each party (Tomz et al., 2002). In order to test for the appropriateness of the SUR, the Breusch-Pagan test is performed for each model.

Two sets of explanatory variables are employed. ${ }^{13}$ First, as this analysis is primarily concerned with the economic determinants of vote choice, a set of regional 
economic indicators, e.g., the unemployment rate in 1990, the percentage change in registered unemployment between each election period (\%), average monthly earning (in CZK, adjusted for inflation with 1990 as the base year), the number of private entrepreneurs (as a percentage of the population, excluding farmers), and the share of employment in industry and agriculture, are included. Second, in order to control for the socio-demographic determinants of voting patterns, a number of indicators such as population density, the number of retirees, university educated and Roman Catholics (all three variables are as a percentage of population), are included as control variables. ${ }^{14}$ In addition, a dummy variable is included to control for Moravian regions, which typically support the Moravian parties ${ }^{15}$, especially in the earlier elections.

Table 3 presents an overview of the explanatory variables used in the analysis. These regional indicators highlight the uneven distribution of the costs and benefits of the transition process. The economic indicators, particularly the unemployment rate, prove the most volatile. Several studies (Fidrmuc, 2000a; Bell, 1997; Pacek, 1994) have cited that increased unemployment has been the most severe outcome of the transition process, rising from an average of $0.71 \%$ in 1990 to $9.94 \%$ in 2002 . As the unemployment rate is one of the primary determinants of voting behaviour, especially in post-communist countries, this analysis focuses on the impact of regional unemployment on election results.

Second, in order to test the hypothesis that expectations of future regional economic conditions influence voting behaviour, and that electoral decisions during the initial stages of the transition process were prospectively orientated, a measure capturing the regions' economic predictions is utilised. This measure is taken from the Economic Expectation and Attitudes (EEA) survey dataset. The EEA surveys were carried out in the Czech Republic between 1990-1998. ${ }^{16}$ Responses to the following 
question were aggregated to the regional level and the mean value calculated: "Looking into the near future, are you afraid of economic development? Do you have a feeling of insecurity? Whereby answers are coded on the following four-point scale: 1=“Definitely yes”, 2=”Rather yes”, 3=“Rather no”, 4=“Definitely no”. This measure captures the extent to which a region believes it will be a "winner" or "loser" in the future. Higher values correspond to regions which are not afraid of economic development, and hence may be characterised as "expected winners" of the transition process, while lower values correspond to regions that fear future economic development and may be characterised as “expected losers”. On average, regions have become more afraid of economic developments over time. The initial optimism of 1990 has been replaced by feelings of insecurity as the outcomes of the reform programs are realised. The variable entitled "Not Afraid of Economic Development 1990” (NAED90), therefore, measures the regions initial prospective outlook in 1990. Table 4 presents the correlation of NAED90 and objective unemployment rates over time. There is a negative and significant relationship between prospective expectations and future economic outcomes with the correlation becoming stronger over time. This suggests that regions which were not afraid of economic development in 1990 subsequently had lower unemployment in the future, suggesting that voters' expectations about future economic conditions proved correct.

\section{$4 \quad$ Results}

There are two stages to the empirical analysis. Section 4.1 estimates three models for each of the five elections, in order to examine the evolution of Czech voting patterns and to test the classic retrospective hypothesis against models of prospective voting. Section 4.2 then focuses on the first election in the post- 
communist period in order to test whether voting behaviour was an outcome of prospective thinking.

\subsection{Models of Czech Voting Behaviour}

Tables 5 to 9 present five sets of regressions estimated for each election, where the dependent variable is the proportion of votes received by Pro-Reform, Centre-Left, Communist and Other parties for the 1992, 1996, 1998 and 2002 elections, and the proportion of votes received by Pro-Reform, Communist and Other parties for the 1990 election (the Centre-Left did not pass the threshold of representation in the first election). Three models are estimated for each election year. Model 1 represents the classic retrospective economic voting model, whereby the change in unemployment during each election period and a series of socio-demographic indicators are related to electoral outcomes. Model 2 then replaces the change in regional unemployment rate with the "Not Afraid of Economic Development 1990" (NAED90) variable, in order to test whether perceptions of the future in 1990 influenced voting behaviour in all five elections. Model 3 combines models 1 and 2 to examine whether prospective judgements made in 1990 are a better determinant of vote choice than economic conditions.

\section{Model 1: The Classic Retrospective Approach}

The retrospective model would predict that support for incumbent parties is negatively related to the unemployment rate in the period prior to the election as they are punished for not improving economic conditions during their time in office. Conversely, support for opposition parties is positively related to the unemployment rate. Therefore if this model holds the Pro-Reform parties should be punished for large 
increases in unemployment between the 1992, 1996 and 1998 elections while they were in power, and the Centre-Left parties should be punished for high unemployment in the 2002 election after winning the 1998 election.

Model 1 in Tables 5-9 displays the effect of the change in unemployment, in addition to several other socio-economic variables, on support for each party group. ${ }^{17}$ First, Tables 5 shows that the election year unemployment rate has little statistical impact on vote choice in the 1990 election, apart from having a weak positive impact on support for the Communists, where it is statistically significant at the $10 \%$ level. As such, these results are as expected given the low unemployment rate across regions in the early transition period. Unemployment started to rise after 1992 as the major economic reforms were initiated. Indeed, Table 6 which analyses the 1992 election, conforms to the retrospective hypothesis. It shows that the percentage change in unemployment between 1990 and 1992 has a negative and statistically significant impact on support for the Pro-Reform group (the incumbents) and negative and significant impact on the Others group. This pattern however disappears in the 1996 and 1998 elections (see Tables 7 and 8), as the change in regional unemployment has no impact on support for any of the parties grouping. Given the large increases in unemployment throughout this period, the retrospective hypothesis would predict that voters would punish the incumbents and reward the opposition parties, however the Czech elections of 1996 and 1998 disputes this hypothesis.

Interestingly, unemployment change does have an impact in the 2002 election (Table 9) when the Centre-Left group was in power. High increases in unemployment increases support for the Pro-Reform parties (the opposition) and reduces support for the Centre-Left and the Communists. It should be noted that 2002 recorded the highest unemployment rate to date in the post-communist period. These results provide some 
evidence in support for the Salient Goal hypothesis whereby governments are punished when their specific policy area is performing badly, therefore left-wing government are punished for high unemployment as seen in the 2002 election. Overall, weak evidence is found in favour of the retrospective hypothesis, as unemployment only has an impact on voting behaviour in 2 of the 5 elections (1992 and 2002). Indeed, these results are in line with Tucker (2004) and Fidrmuc (2000) who also find that the responsibility hypothesis does not hold in transition economies.

\section{Models 2 and 3: Initial Expectations and Voting Patterns}

Model 2 in Tables 5-9 replaces the change in regional unemployment with the “Not Afraid of Economic Development 1990” variable (NAED90 henceforth), which captures the regions' initial predictions about the future. Model 3 then includes both the unemployment measure and the NAED90 measure in order to test which variable has the greater impact on vote choice (see Table 4 for the correlation of these two measures over time). Table 5 shows that, unlike the unemployment indicator, the NAED90 measure has a significant impact on all three party groups in the 1990 election. Regions that are not afraid of economic development in the future show greater support for Pro-Reform parties, than for the Communists or Others. This effect is replicated in model 3, suggesting that predictions about the future had a greater effect on vote choice in the 1990 election than contemporary economic indicators. This provides evidence that voting behaviour in the first free election in the postcommunist period was prospectively orientated, whereby regions, taking their initial endowments into consideration, formed judgements about how they would fare in the new economic system. Regions that feared economic development in the future voted for either Communist or Other parties, in the hope of either delaying or halting 
economic reforms, while regions that were optimistic about the future, supported ProReform parties in order to accelerate the reform process.

A similar pattern emerged in the 1992 election (Table 6), whereby NAED90 has a positive and significant effect on the Pro-Reform parties and a negative effect on the Communist and Other parties. Model 3 which includes both the percentage change in unemployment between 1990-1992 and the NAED90 measure, shows that predictions about future economic outcomes has a stronger impact on vote choice than the unemployment measure. The 1996 election (Table 7) deviates from this pattern slightly, in that the NAED90 measure has no statistical effect on support for the Centre-Left, Communist or Other groups, and only has a positive and weakly significant (10\%) effect on support for the Pro-Reform parties. However, model 3 shows that the subjective NAED90 measure does impact vote choice unlike the objective unemployment measure. Model 2 of the 1998 election (Table 8) shows that these initial economic forecasts (NAED90) again impact on the 1998 vote choices regions with optimistic expectations display greater support for Pro-Reform parties than the Centre-Left, Communist or Other parties. Model 3 shows that the change in regional unemployment between 1996 and 1998 has no influence voting decisions in the 1998 election while NAED90 has a strong impact on electoral outcomes, again suggesting that economic forecasts made in 1990 have a greater impact on election outcomes than contemporary economic indicators. Finally, both models 2 and 3 in Table 9 show that a region's predictions of the future in 1990 continue to influence voting decisions in the 2002 election, i.e., twelve years after the initial forecasts were made.

Overall, these results indicate that economic conditions influence electoral outcomes in the later elections, however they also show that expectations of these 
economic conditions formed in 1990 are often a better determinant of vote choice than election year economic indicators. One possible explanation for this phenomenon is that given future economic conditions were anticipated in 1990, when the economic outcomes were actually realised, contemporary economic conditions had little impact on the election outcomes as they were already incorporated into the voter's decision set. ${ }^{18}$ It should also be noted that models including the NAED measure for 1992, 1996 and $1998^{19}$ were also estimated. Interestingly, these models show that 1990 expectations are better determinants of vote choice than election year predictions. ${ }^{20}$ The impact of the socio-economic and demographic variables on vote choice is discussed below.

\section{Socio-Economic and Demographic Factors}

While the primary motivation of this analysis is to examine how unemployment, the most salient outcome of the transition process, influences voting behaviour, additional factors that capture the regions' initial endowments are also included. Tables 5-9 show that \% entrepreneurship, \% Roman Catholic, \% university educated and the Moravian dummy have a persistent and stable effect on vote choice across all election years. Average wages, \% retired, population density and industrial and agricultural employment only have a weak and inconsistent effect on vote choice. The most stable determinant of regional vote choice is the proportion of entrepreneurs within the regional population (excluding farmers). Across all four elections ${ }^{21}$, regions with a high proportion of entrepreneurs display positive support for Pro-Reform parties, and negative support for the Communist and Centre-Left groups. As private entrepreneurs are the chief beneficiaries of an open market economy, it is unsurprising 
that they are the main supporters of Pro-Reform parties, and indeed that they are overtly opposed to advocates of socialist or social-democratic systems.

A second stable determinant of voting patterns is the proportion of Roman Catholics in a region. This variable is included to control for support for the Christian Democratic Union (KDU), which is incorporated into the Pro-Reform group. As expected, regions with a high proportion of Roman Catholics show positive support for the Pro-Reform parties and negative support for Communist, Centre-Left and Other groups. While there is some variation across elections, this effect remains relatively constant. Similarly, a university-education measure is included to capture the quality of the regions' labour force. Regions with a greater number of university graduates show higher support for Pro-Reform parties, less support for Communist parties, while having no statistical impact on support for Centre-Left parties (apart from the 1998 results). Regions with a highly qualified labour force are likely to outperform regions with a low-skilled labour force, as they are more adaptable to the inevitable changes which the transition process brings. Finally, the Moravian dummy shows that Moravian regions have a greater probability of voting for Communist or Other parties than Pro-Reform parties.

Another factor that typically influences vote choice in economic voting studies is average wages, whereby higher (lower) wages correspond to support for right-wing (left-wing) parties. This classic hypothesis however, does not hold for countries undergoing transition. Average regional wages (adjusted for inflation) only have a weak impact on vote choice and influence it in apparently contradicting ways, i.e., high wage regions show greater support for the Communists in the 1990, 1992 and 1998 elections. A possible explanation for this is that despite aspirations for low income inequality, under the communist regime coal-mining regions had above 
average wage levels. While wages in these regions in the post-communist period have fallen, they remain at about the industrial average (see Myant, 2003). Typically, bluecollar workers, such as miners, form the natural constituency of Communist voters (in this case to campaign for continued mining activity), hence such high wage regions show support for the Communist parties.

As the transition process often has adverse effects on the elderly, a variable capturing the proportion of retirees in each region is included. Tables 5-9 show that this hypothesis is refuted, as retirees show greater support for Pro-Reform parties, and are less likely to support Centre-Left parties, while having no effect on support for the Communist party. However these effects are weak and inconsistent across elections. Next, in order to capture difference in voting behaviour between urban and rural areas, a measure of population density is included as a proxy for this in all models. As it does not have an impact on vote choice, such an urban-rural distinction is not found.

The evolution of the service sector, and the subsequent downsizing of industrial and agricultural sectors is another major outcome of the transition process. One would expect regions with a high dependency on industrial and agricultural employment to display less support for Pro-Reform parties than the Centre-Left or Communist parties. However, the impact of these variables on electoral support is rather weak. Regions with a high dependency on agriculture show greater support for the Communists in the 1996 and 1998 election and the Centre-Left in the 1992 and 2002 election. The effect of industry is even weaker - contrary to a priori expectations, highly industrialised regions show less support for the Communist parties, and greater support for Pro-Reform parties across all four elections. These results follow Fidrmuc (2000), which also finds that these variables do not strongly influence vote choice. In 
order to examine whether initial expectations formulated in 1990 proved correct, section 4.2 analyses the 1990 election in more detail.

\subsection{The 1990 Election: The Case of Prospective Thinking?}

This section examines whether prospective judgements formed in 1990 were informative with respect to the subsequent outcome of the economic reforms. Table 10 estimates 2 models of the 1990 election. Model 1 tests the impact of the 2002 unemployment rate on 1990 election results and model 2 then includes both the 1990 and 2002 regional unemployment rate. If the future unemployment rate proves significant it would suggest that voters accurately predicted their future economic conditions on the eve of the transition period.

Table 5 above shows the 1990 unemployment rate has no statistical impact on support for the Pro-Reform or Other parties, while only having a weak (at the $10 \%$ level) positive effect on support for the Communist party. Model 1 in Table 10, however, indicates that the 2002 unemployment rate has a far greater impact on 1990 voting behaviour, whereby it has a negative and statistically significant impact (at the 1\% level), on support for Pro-Reform parties, and a positive and statistically significant effect on support for both the Communist (at the $10 \%$ level), and Other parties (at the 1\% level). Model 2, which includes both the 1990 and 2002 regional unemployment rates, shows that the 2002 measure consistently outperforms the 1990 measure. It has a negative and significant effect on support for the Pro-Reform parties and a positive and significant effect on support for Other parties, while the 1990 measure has no statistical effect on support for any of the party groups.

Overall, the significant impact of 2002 unemployment rates on initial electoral decisions suggests that regions were prospectively orientated in 1990 and that these 
predictions turned out to be accurate. An alternative explanation for these results, however, is that the causality runs in the opposite direction, whereby voting patterns in 1990 actually led to unemployment through electoral engineering on the part of the incumbent government. This occurs when an incumbent government favours regions in which they derive their support by implementing favourable policies in those regions, while punishing regions that vote for other parties. In the Czech context, regions that voted for Pro-Reform parties in 1990 subsequently had lower unemployment rates in later years, while regions that voted for left-wing parties in 1990 had higher unemployment rates.

If the electoral engineering hypothesis is true, then the relationship between future unemployment rates and 1990 voting behaviour should be stronger for the early to mid 1990's when the Pro-Reform government was in power, than the late 1990's when the Centre-Left government was in power. Once the Centre-Left (CSSD) government took over in 1998, given that the left-leaning regions with high unemployment rates are their main supporters, they should stop and/or reverse this punishment strategy, by adopting policies that favour these regions. Therefore, in order to test whether this hypothesis is true, three models capturing the impact of the 1992, 1996 and 1998 unemployment rates on 1990 regional election results are estimated. If the electoral engineering hypothesis holds the 1992, 1996 and 1998 unemployment rates should have a greater impact on 1990 voting behaviour than the 2002 unemployment rates.

These results are reported in Table 11. Each of the four models show that the unemployment rates in all four years exerts the same influence on 1990 election results, i.e., they have a negative and significant impact on support for the Pro-Reform parties and a positive and significant effect on support for the Communists and Other 
parties. Therefore, the relationship between 1990 voting patterns and the 2002 unemployment rate is just as strong as its relationship with the 1992, 1996 and 1998 unemployment rates, even though a right-wing Pro-Reform government was in power at the start of the 1990's and a left-wing government was in power in the later stages of the transition process. This suggests electoral engineering was not employed during the transition process and that voting behaviour during the earlier election did not create unemployment in the later stages. The causality runs in the opposite direction, as expected. Overall, these results provide evidence that regions were prospectively orientated in 1990 and that these predictions turned out to be accurate.

One could question why voters continued to participate in elections at all, given that the regional problems were structural, and as such, future economic outcomes could be predicted in 1990. However, Downs (1957), Riker and Ordeshook (1968) and Orviska et al. (2001) argue that individuals gain utility from voting and that they vote in order to fulfil a civic duty, partly out of fear that democracy will collapse without such participation. This concern is even more relevant in young democratising countries, such as the Czech Republic. Therefore, while the outcomes of the transition process were, to an extent, anticipated, the newly endowed privilege of voting in elections and the desire to maintain and support the new democracy, encouraged voters to participate in the post-communist elections. In addition, voters in regions with bad initial conditions in 1990 could foresee that the economic reform program would have a detrimental effect on their regions development. Indeed, these expectations turned out to be accurate, however, they continued to participate in elections and vote for more left-wing parties in the hope of softening the burden of these unfavourable economic conditions by voting for parties favouring more expansionary monetary and fiscal policies. So while these regions subsequently had 
higher unemployment than regions which with good economic conditions in 1990, they continued to vote for such parties in order to offset their economic misfortune through social safety nets, such as increased unemployment benefits.

\section{Discussion}

Despite the initial euphoria following the Velvet Revolution, the Czech Republic's first free election in forty-four years yielded varying levels of regional support for the new-regime parties, hence contesting the conventionally held belief that support for the new economic and political system was homogenous. Such regional variation in voting patterns was not matched with analogous patterns in regional economic conditions, as implied by the classic retrospective economic voting hypothesis. Czech regions at the start of the transition period were characterised by relatively low and uniform unemployment rates. Therefore, initial trends in voting patterns were consolidated at a time when contemporary economic cues did not exist. Voters could not base their political judgements on economic developments of the past, but rather were forced to look to the future in order to predict their standing in the new market economy, and vote accordingly in an attempt to optimise this position. This paper proposes that voting in transition economies was prospective, such that voters could accurately predict the effects of the economic reform program, and internalising these predictions, formed vote choices that would persist throughout the transition period.

Regions that initially voted for right-wing Pro-Reform parties in the 1990 election did so with a belief that economic development was a good thing and that they would survive and thrive in an open market economy. Voting for such parties would ensure fast-speed reforms and rapid access to the opportunities presented by the 
new market economy. As such, these regions foresaw they would become the "winners" of the transition process. "Winner" regions were typically endowed with good initial conditions, such as greater pre-transition trade to thriving market economies, good infrastructure, and a well-educated labour force. These regions, which continued to support Pro-Reform parties, subsequently had lower unemployment rates, therefore signifying that their initial predictions, which were formed by taking account of these initial endowments rather than contemporary economic conditions, proved correct, even twelve years after the first election.

Conversely, regions that supported left-wing parties in the first election, believed economic reforms would have an adverse effect on their regional development, albeit relative to the "winner" regions. These "loser" regions were characterised by poor initial conditions, such as a reliance on CMEA orientated trade, over-industrialisation and a high dependence on a single industry, e.g., coal mining. The optimal strategy for these regions was to support left-wing parties, which advocated high social welfare spending and a strong state, in the hope of either maintaining the status quo or help in alleviating the outcomes induced by harsh reforms. The "loser" regions subsequently had higher unemployment in the later stages of transition, again suggesting that initial predictions of future outcomes proved accurate.

Political constraints are central to the theoretical literature on the economics of transition. These constraints assume that voters, with rational expectations, taking stock of endowments from the planning era, can predict, under some uncertainty, whether they would become "winners" or "losers" of reform. This assumes, in the language of political scientists, that prospective economic voting is binding. This study tests both the retrospective and prospective economic voting models and finds 
that, contrary to Western literature, economic voting in the Czech Republic, based on initial economic endowments, was prospective in the first election in the postcommunist period. This study also shows that regional voting patterns, which were formed in the early stages of the transition process, persisted over time and that the realized economic conditions reflected prospective thinking in 1990. 


\section{Endnotes}

${ }^{1}$ See Roland (2002) for a survey of this literature.

${ }^{2}$ Note that older voters may have participated in the inter-war election elections between 1920 and 1935, and therefore may have experience of competitive political parties.

${ }^{3}$ In addition, Valev (2004), using individual data, guards us against the use of unemployed status as a proxy for support for anti-reform parties. Individuals understand whether they are in a state of temporary (frictional) rather than permanent (structural) unemployment as a result of the reform process.

${ }^{4}$ While tests of the retrospective/prospective debate have been limited in post-communist studies, the literature on economic voting in the emerging democracies of Latin America have found evidence which disputes the classical retrospective model. Indeed, Stokes (1996) and Weyland (1998), who examine Peruvian and Venezuelan voters respectively, both find that despite painful economic reforms, voters tend to be prospectively orientated and are willing to accept short-term economic pains. Similarly, Gelineau (2001) finds that Argentinean voters in times of economic upheaval and reforms tend to contradict the classic economic voting view such that they are prospectively orientated.

${ }^{5}$ Industrial organization theory has identified two types of export industries in transition economies. First, industries that exported to the CMEA (Council for Mutual Economic Assistance) market under communism have lower probability of surviving the transition process as their goods are generally of a lower quality and become obsolete. Second, firms that exported to the West under communism have a higher probability of surviving and prospering in transition (see Repkine and Walsh, 1999).

${ }^{6}$ Both the former Polish and Hungarian communist parties successfully shed their communist image and renamed themselves the Democratic Left Alliance (SLD), and the Socialist Party (MSzP) respectively.

${ }^{7}$ Warner (2001), for Russia, asks whether support for reform can fall or grow during the transition process. Clearly, the perceived success or failure of reform could lead to voters switching and thus create volatility. Evidence of positive feedback is found in Russia. For the Czech Republic we observe a dominance of persistence in regional pro-reform voting with some movement to the centre left on the margin overtime. 
${ }^{8}$ Anderson and O’Connor (2000) examine the convergence of economic perceptions among East and West Germans, and finds that in systems undergoing change, knowledge improves over time as one has more experience with it.

${ }^{9}$ The electoral data was obtained from the Czech Statistics Office for the 1990 and 1992 elections and from the official Czech election website at www.volby.cz for the subsequent elections.

${ }^{10}$ There are presently 77 regions in the Czech Republic, as the district of Jesenik was created in 1996 from parts of Sumperk and Bruntal. However, in order to maintain consistency in the analysis Jesenik is excluded from the analysis throughout, and the analysis is performed for the original 76 regions.

11 This methodological overview is based on Fridmuc and Doyle (2004).

${ }^{12}$ Tomz et al. (2002) report that out of nineteen articles analysing multiparty election data published in leading political science journals between 1996-2000, eighteen use OLS.

${ }^{13}$ Regional economic and demographic variables were all obtained from Czech Statistical Yearbooks 1990-2002.

${ }^{14}$ Note that while the economic indicators correspond to the election year values, such yearly indicators were not available for the demographic variables, therefore, the nearest year available was used. As demographic indicators are generally stable overtime this should not be problematic.

${ }^{15}$ Such as the Movement for Self-Governing Democracy - Association for Moravia and Silesia (HSDSMS), later HSDMS (Movement for Self-Governing Democracy of Moravia and Silesia).

${ }^{16} 11$ EEA surveys were conducted semi-annually (1990-1992) and annually (1993-1998) by the socioeconomic team of the Institute of Sociology, Academy of Sciences Czech Republic. The surveys focus on attitudes concerning economic transformation, voting preferences, political identification, trust in institutions, satisfaction with the political regime and the openness of the economy in general. They also contain a battery of questions detailing the socio-economic background of respondents, in addition to their district of residence. A large number of the questions are repeated every year, which enables the analysis of changes in attitudes over time. Overall 11 EEA surveys were conducted between 1990 and 1998, containing between 1113 and 2084 observations and approximately 130 variables in each survey. The sampling methodology involved two steps: first, stratification by settlement size and region, and second, quota sampling by age, gender and education. Hence the procedure ensures the sample is representative of the Czech population. The EEA surveys have remained a largely untapped source of data, especially with respect to political preferences and voting behaviour during transition. 
${ }^{17}$ Note that when modelling the 1990 election the unemployment rate is used rather than the percentage change in unemployment between the election periods, as 1990 was the first free election in the postcommunist period.

${ }^{18}$ Similarly, Palmer and Whitten (1999) posit that voters are primarily concerned with the unexpected, rather than the expected, components of inflation and growth, as the unexpected components have real income effects and are a better indicator of government competence. Using data from 19 industrialized economies between 1970-94, they find stronger electoral effects for the unexpected components of inflation and growth, than their overall levels.

${ }^{19}$ As the last EEA survey was conducted in 1998, there is no such measure for 2002 model.

20 These results are available upon request.

${ }^{21}$ Unfortunately, the entrepreneurship and sectoral variables are not available for the 1990 period and hence are excluded from the 1990 models. 


\section{References}

Anderson, Christopher J., O’Connor, Kathleen M., 2000. System change, learning and public opinion about the economy. British Journal of Political Science 30(1): 147172.

Bell, Janice, 1997. Unemployment Matters: Voting patterns during the economic transition in Poland, 1990-1995. Europe-Asia Studies 49(7): 1263-1291.

Birch, Sarah, 2001. Electoral systems and party system stability in post-communist Europe. Paper prepared for the $97^{\text {th }}$ Annual meeting of the American Political Science Association, San Francisco, $30^{\text {th }}$ August- $2^{\text {nd }}$ Sept.

Colton, Timothy J., 1996a. Economics and voting in Russia. Post-Soviet Affairs 12(4): 289-318.

Dewatripont, Mathias, Roland, Gérald, 1995. The design of reform packages under uncertainty. American Economic Review 85: 1207-1223.

Downs, Anthony, 1957. An Economic Theory of Democracy. Harper \& Row, New York.

Fidrmuc, Jan, 2000a. Economics of voting in post-communist countries. Electoral Studies 19 (2/3): 199-217.

Fidrmuc, Jan, 2000b. Political support for reforms: economics of voting in transition countries. European Economic Review 44: 1491-1513.

Fidrmuc, J. and Doyle, O., 2004. Voice of the Diaspora: An Analysis of Migrant Voting Behaviour. William Davidson Institute (WDI) Working Paper No. 712, July 2004. CEPR Discussion Paper No. 4619 (September 2004).

Gelineau, François, 2001.Linking micro-politics to macroeconomics: Economic voting in volatile contexts (The Argentine case). University of New Mexico. 
Gibson, John, Cielecka, Anna, 1995. Economic influences on the political support for market reforms in post-communist transitions: Some evidence from the 1993 Polish parliamentary elections. Europe-Asia Studies 47(5): 765-85.

Greene, William H., 2000. Econometric Analysis. $4^{\text {th }}$ Edition, Prentice Hall, Upper Saddle River, NJ.

Harper, Marcus, 2000. Economic voting in post-communist Eastern Europe. Comparative Political Studies 33(9): 1191-227.

Jackson, John E., 2002. A seemingly unrelated regression model for analyzing multiparty elections. Political Analysis 10: 49-65.

Jehlicka, Petr, Kostelecky, Tomas, Sykora, Ludek, 1993. Czechoslovak parliamentary elections in 1990: Old patterns, new trends and lots of surprises. In Loughlin, John, Van Der Wusten, Herman. The New Political Geography of Eastern Europe. Belhaven Press.

Mason, David S. and Sidorenenko-Stephenson, Svetlana, 1997. Public opinion and the 1996 elections in Russia: Nostalgic and statist, yet pro-market and pro-Yeltsin. Slavic Review 56(4): 698-717.

Mateju, Petr, Rehakova, Blanka, 1996. Turning left or class realignment? Analysis of the changing relationship between class and party in the Czech Republic 19921996. Social Trends 1/1996. Czech Academy of Science.

Myant, Martin, 2003. EU Accession and Czech regional differences. Paper presented at Regional Studies Conference, Pisa, Italy.

Narwa, Daniel, 1997. An analysis of electoral changes: The case of the Czech Republic. Essex papers in politics and government, No. 118. Department of Government, University of Essex. 
Orviska, Marta, Caplanova, Anetta, Hudson, John, 2001. Voting, civic duty and transaction costs in transition countries. CERGE-EI Working paper.

Pacek, Alexander, 1994. Macroeconomic conditions and electoral politics in East Central Europe. American Journal of Political Science 38(3): 723-744.

Palmer, Harvey D., Whitten. Guy D., 1999. The electoral impact of unexpected inflation and economic growth. British Journal of Political Science 29: 623-39.

Powers, Denise V., Cox, James H., 1997. Echoes from the past: The relationship between satisfaction with economic reforms and voting behavior in Poland. American Political Science Review 91(3): 617-633.

Walsh, P.P. and Repkine, A., 1999. European Trade and Foreign Direct Investment UShaping Industrial Output in Central and Eastern Europe: Theory and Evidence. Journal of Comparative Economics 27(4): 730-752.

Riker, William H., and Ordeshook, Peter C., 1968. A theory of the calculus of voting. American Political Science Review 62: 25-42.

Roland, Gerard, 2002. The political economy of transition. Journal of Economic Perspectives 16(1): 29-51.

Stokes, Susan, 1996. Economic reform and public opinion in Peru, 1990-1995. Comparative Political Studies 29:544-66. Public Support for Emerging Democracies, special issue ed. Susan Stokes.

Tomz, Michael, Tucker, Joshua. and Wittenburg Jason, 2002. A convenient statistical model for multiparty electoral data. Political Analysis 10(1): 66-83.

Tucker, Joshua, 2000. It’s the Economy, Comrade! Economic Conditions and Election Results in Post-Communist Russia, Poland, Hungary, Slovakia and the Czech Republic from 1990-1996. PhD thesis. Harvard University. 
Tucker, Joshua, 2001. Economic conditions and the vote for incumbent parties in Russia, Poland, Hungary, Slovakia and the Czech Republic from 1990-1996. Post-Soviet Affair 17(4): 309-31.

Tucker, Joshua, 2004. Transitional economic voting: Economic conditions and election results in Russia, Poland, Hungary, Slovakia, and the Czech Republic from 1990-1999. Princeton University, mimeo.

Valev, Neven, 2004. No pain, no gain: Market Reform, unemployment and politics in Bulgaria. Journal of Comparative Economics 32: 409-425.

Warner, Andrew M., 2001. Is economic reform popular at the polls? Russia 1995. Journal of Comparative Economics 29: 448-465.

Weyland, Kurt, 1998. Peasants or Bankers in Venezuela? Presidential Popularity and Economic Reform Approval, 1989-1993. Political Research Quarterly 51(2): 341362. 


\section{Tables}

Table 1 Political Spectrum of the Czech Republic

\begin{tabular}{l|l|l|l}
\hline & PRO-REFORM & CENTRE -LEFT & COMMUNIST \\
\hline $\mathbf{1 9 9 0}$ & Civic Forum, KDU-CSL & $\sim$ & KSCM \\
$\mathbf{1 9 9 2}$ & ODS-KDS, ODA, OH, KDU-CSL & CSSD, LSU & LEFT BLOC \\
$\mathbf{1 9 9 6}$ & ODS, ODA, KDU-CSL & CSSD & KSCM \\
$\mathbf{1 9 9 8}$ & ODS, US, KDU-CSL & CSSD & KSCM \\
$\mathbf{2 0 0 2}$ & ODS, Coalition (KDU-CSL and US-DEU) & CSSD & KSCM \\
\hline
\end{tabular}

Table 2 Regional Variations in Voting Patterns

\begin{tabular}{l|c|c|c|c}
\hline$\%$ & Pro-Reform & Communist & Centre-Left & Other \\
\hline 1990 & 57.37 & 13.77 & $\sim$ & 28.84 \\
& $(7.01)$ & $(2.37)$ & & $(6.60)$ \\
1992 & 44.1 & 14.58 & 14.59 & 26.68 \\
& $(5.95)$ & $(2.67)$ & $(3.71)$ & $(5.37)$ \\
1996 & 41.71 & 11.05 & 26.99 & 20.26 \\
& $(6.25)$ & $(2.22)$ & $(4.18)$ & $(2.69)$ \\
1998 & 42.92 & 11.89 & 33.22 & 11.96 \\
& $(6.47)$ & $(2.50)$ & $(3.97)$ & $(1.62)$ \\
2002 & 36.72 & 19.99 & 30.36 & 12.94 \\
& $(5.14)$ & $(4.09)$ & $(2.92)$ & $(1.66)$ \\
\hline
\end{tabular}

Note: Means are computed as averages across regions, with standard errors in parenthesis.

Table 3 Descriptive Statistics of Explanatory Variables

\begin{tabular}{l|c|c|c|c|c}
\hline Explanatory Variables & $\mathbf{1 9 9 0}$ & $\mathbf{1 9 9 2}$ & $\mathbf{1 9 9 6}$ & $\mathbf{1 9 9 8}$ & $\mathbf{2 0 0 2}$ \\
\hline Unemployment Rate [\%] & 0.71 & 2.90 & 3.79 & 7.81 & 9.94 \\
& $(0.34)$ & $(1.41)$ & $(1.91)$ & $(3.06)$ & $(4.15)$ \\
Average Wage [adjusted, 1990 base] & 3262.50 & 2625.53 & 3292.56 & 3408.69 & 3739.35 \\
& $(145.60)$ & $(207.05)$ & $(286.70)$ & $(413.98)$ & $(366.04)$ \\
Entrepreneurs [\% of pop] & $\sim$ & 9.08 & 10.18 & 12.72 & 13.81 \\
& & $(1.99)$ & $(1.69)$ & $(2.59)$ & $(2.65)$ \\
Industry [\% of employment] & $\sim$ & 38.32 & 55.44 & 42.50 & 46.21 \\
Agriculture [\% of employment] & & $(7.63)$ & $(9.64)$ & $(7.80)$ & $(10.09)$ \\
& $\sim$ & 11.69 & 13.28 & 8.26 & 7.92 \\
Population Density & 210.74 & $(6.43)$ & $(7.62)$ & $(4.99)$ & $(3.62)$ \\
& $(395.32)$ & $(39.31$ & 208.19 & 207.38 & 204.07 \\
Retiree [\% of pop] & 20.08 & 20.08 & $(388.66)$ & $(385.60)$ & $(372.23)$ \\
University Educated [\% of pop] & $(2.16)$ & $(2.16)$ & $(2.16)$ & 20.08 & 13.64 \\
& 5.51 & 5.51 & 5.51 & 7.07 & $(1.32)$ \\
Roman Catholic [\% of pop] & $(2.08)$ & $(2.08)$ & $(2.08)$ & $(2.44)$ & $(2.07$ \\
Moravian Minority Dummy & 39.55 & 39.55 & 39.59 & 39.59 & 39.59 \\
Not Afraid of Economic Development & $(14.25)$ & $(14.25)$ & $(14.16)$ & $(14.16)$ & $(14.16)$ \\
\hline
\end{tabular}

Note: Means are computed as averages across regions, with standard errors in parenthesis.

Sources: All regional data was taken from various Czech Statistical Yearbooks, except the "Not Afraid of Economic Development” measure which was taken from the Economic Expectation and Attitude (EEA) Surveys.

Table 4 Correlation of Regional UE Rates and Expectations of the Future

\begin{tabular}{l|c|c|c|c|c}
\hline & UE 1990 & UE 1992 & UE 1996 & UE 1998 & UE 2002 \\
\hline $\begin{array}{l}\text { Not Afraid of Economic } \\
\text { Development 1990 }\end{array}$ & $-0.245^{* *}$ & -0.184 & $-0.227^{*}$ & $-0.224^{*}$ & $-0.250^{* *}$ \\
\hline $\begin{array}{l}\text { Election Year Not Afraid of } \\
\text { Economic Development }\end{array}$ & $-0.245^{* *}$ & -0.017 & -0.151 & -0.027 & $\sim$ \\
\hline
\end{tabular}


Table 5 SUR Determinants of 1990 National Election Results in Czech Regions

\begin{tabular}{|c|c|c|c|c|c|c|c|c|c|}
\hline \multirow{2}{*}{1990} & \multicolumn{3}{|c|}{ Model 1} & \multicolumn{3}{|c|}{ Model 2} & \multicolumn{3}{|c|}{ Model 3} \\
\hline & Pro-Reform & Communist & Others & Pro-Reform & Communist & Others & Pro-Reform & Communist & Others \\
\hline Not Afraid 1990 & $\sim$ & $\sim$ & $\sim$ & $\begin{array}{c}6.715^{* * *} \\
(1.658)\end{array}$ & $\begin{array}{c}-1.703 * * \\
(0.719)\end{array}$ & $\begin{array}{c}-4.846^{* * *} \\
(1.343)\end{array}$ & $\begin{array}{c}6.893 * * * \\
(1.686)\end{array}$ & $\begin{array}{c}-1.514^{* *} \\
(0.724)\end{array}$ & $\begin{array}{c}-5.231 * * * \\
(1.349)\end{array}$ \\
\hline Unemployment & $\begin{array}{c}-0.398 \\
(1.870) \\
\end{array}$ & $\begin{array}{c}1.294 * \\
(0.751) \\
\end{array}$ & $\begin{array}{r}-1.015 \\
(1.479) \\
\end{array}$ & $\sim$ & $\sim$ & $\sim$ & $\begin{array}{l}0.948 \\
(1.731) \\
\end{array}$ & $\begin{array}{l}1.008 \\
(0.743) \\
\end{array}$ & $\begin{array}{r}-2.045 \\
(1.385) \\
\end{array}$ \\
\hline Average Wage & $\begin{array}{l}0.001 \\
(0.005)\end{array}$ & $\begin{array}{c}0.003^{*} \\
(0.002)\end{array}$ & $\begin{array}{l}-0.004 \\
(0.004)\end{array}$ & $\begin{array}{l}0.002 \\
(0.004)\end{array}$ & $\begin{array}{c}0.003 * \\
(0.002)\end{array}$ & $\begin{array}{l}-0.005 \\
(0.003)\end{array}$ & $\begin{array}{l}0.002 \\
(0.004)\end{array}$ & $\begin{array}{c}0.003 * \\
(0.002)\end{array}$ & $\begin{array}{l}-0.005 \\
(0.003)\end{array}$ \\
\hline Population Density & $\begin{array}{l}-0.002 \\
(0.002)\end{array}$ & $\begin{array}{l}0.000 \\
(0.001)\end{array}$ & $\begin{array}{l}0.002 \\
(0.002)\end{array}$ & $\begin{array}{l}-0.002 \\
(0.002)\end{array}$ & $\begin{array}{l}0.000 \\
(0.001)\end{array}$ & $\begin{array}{l}0.002 \\
(0.002)\end{array}$ & $\begin{array}{l}-0.002 \\
(0.002)\end{array}$ & $\begin{array}{l}0.000 \\
(0.001)\end{array}$ & $\begin{array}{l}0.002 \\
(0.002)\end{array}$ \\
\hline Retired & $\begin{array}{l}0.039 \\
(0.308)\end{array}$ & $\begin{array}{l}0.203 \\
(0.124)\end{array}$ & $\begin{array}{c}-0.214 \\
(0.244)\end{array}$ & $\begin{array}{l}-0.091 \\
(0.275)\end{array}$ & $\begin{array}{l}0.195 \\
(0.119)\end{array}$ & $\begin{array}{c}-0.075 \\
(0.223)\end{array}$ & $\begin{array}{l}-0.056 \\
(0.282)\end{array}$ & $\begin{array}{c}0.231 * \\
(0.121)\end{array}$ & $\begin{array}{l}-0.150 \\
(0.225)\end{array}$ \\
\hline University Educated & $\begin{array}{c}1.005 * * \\
(0.462)\end{array}$ & $\begin{array}{c}-0.523 * * * \\
(0.186)\end{array}$ & $\begin{array}{l}-0.496 \\
(0.366)\end{array}$ & $\begin{array}{c}1.076^{* * *} \\
(0.412)\end{array}$ & $\begin{array}{c}-0.486 * * * \\
(0.179)\end{array}$ & $\begin{array}{c}-0.608 * \\
(0.334)\end{array}$ & $\begin{array}{c}1.025^{* *} \\
(0.421)\end{array}$ & $\begin{array}{c}-0.540 * * * \\
(0.181)\end{array}$ & $\begin{array}{l}-0.500 \\
(0.337)\end{array}$ \\
\hline Roman Catholic & $\begin{array}{c}0.159 * * * \\
(0.057)\end{array}$ & $\begin{array}{c}-0.062 * * * \\
(0.023)\end{array}$ & $\begin{array}{c}-0.097 * * \\
(0.045)\end{array}$ & $\begin{array}{c}0.167 * * * \\
(0.052)\end{array}$ & $\begin{array}{c}-0.066 * * * \\
(0.022)\end{array}$ & $\begin{array}{c}-0.100 * * \\
(0.042)\end{array}$ & $\begin{array}{c}0.169 * * * \\
(0.052)\end{array}$ & $\begin{array}{c}-0.064 * * * \\
(0.022)\end{array}$ & $\begin{array}{c}-0.104^{* *} \\
(0.041)\end{array}$ \\
\hline Moravian dummy & $\begin{array}{c}-12.930 * * * \\
(1.760)\end{array}$ & $\begin{array}{c}-0.094 \\
(0.707)\end{array}$ & $\begin{array}{c}13.097 * * * \\
(1.392)\end{array}$ & $\begin{array}{c}-12.755^{* * *} \\
(1.525)\end{array}$ & $\begin{array}{l}0.194 \\
(0.661)\end{array}$ & $\begin{array}{c}12.606 * * * \\
(1.235)\end{array}$ & $\begin{array}{c}-13.024^{* * * *} \\
(1.599)\end{array}$ & $\begin{array}{c}-0.093 \\
(0.687)\end{array}$ & $\begin{array}{c}13.187^{* * * *} \\
(1.279)\end{array}$ \\
\hline Constant & $\begin{array}{c}45.908 * * * \\
\quad(17.690)\end{array}$ & $\begin{array}{l}3.222 \\
(7.101)\end{array}$ & $\begin{array}{c}50.029 * * * \\
(13.990)\end{array}$ & $\begin{array}{l}27.212 \\
(16.892)\end{array}$ & $\begin{array}{l}8.989 \\
(7.325)\end{array}$ & $\begin{array}{l}62.271 * * * \\
\quad(13.681)\end{array}$ & $\begin{array}{l}25.157 \\
(17.270)\end{array}$ & $\begin{array}{l}6.804 \\
(7.414)\end{array}$ & $\begin{array}{c}66.704^{* * *} \\
\quad(13.816)\end{array}$ \\
\hline $\mathrm{R}^{2}$ & 0.524 & 0.327 & 0.664 & 0.609 & 0.359 & 0.710 & 0.610 & 0.374 & 0.718 \\
\hline $\begin{array}{l}\text { Breusch-Pagan } \\
\text { Test }\end{array}$ & \multicolumn{3}{|c|}{$\chi^{2}(3)=103.96 * * *$} & \multicolumn{3}{|c|}{$\chi^{2}(3)=91.63^{* * *}$} & \multicolumn{3}{|c|}{$\chi^{2}(3)=94.96^{* * *}$} \\
\hline
\end{tabular}

Notes: Number of observations is 76. Standard errors are in parentheses. Estimated using a Seemingly Unrelated Regression (SUR) model. The Breusch-Pagan test of independence indicates that we can reject the null hypothesis of independence of the residuals across the equations. Therefore, OLS estimates would be inconsistent and the choice of SUR is justified. Significance levels are indicated as $1 \%(* * *), 5 \%(* *)$ and $10 \%(*)$. 
Table 6 SUR Determinants of 1992 National Election Results in Czech Regions

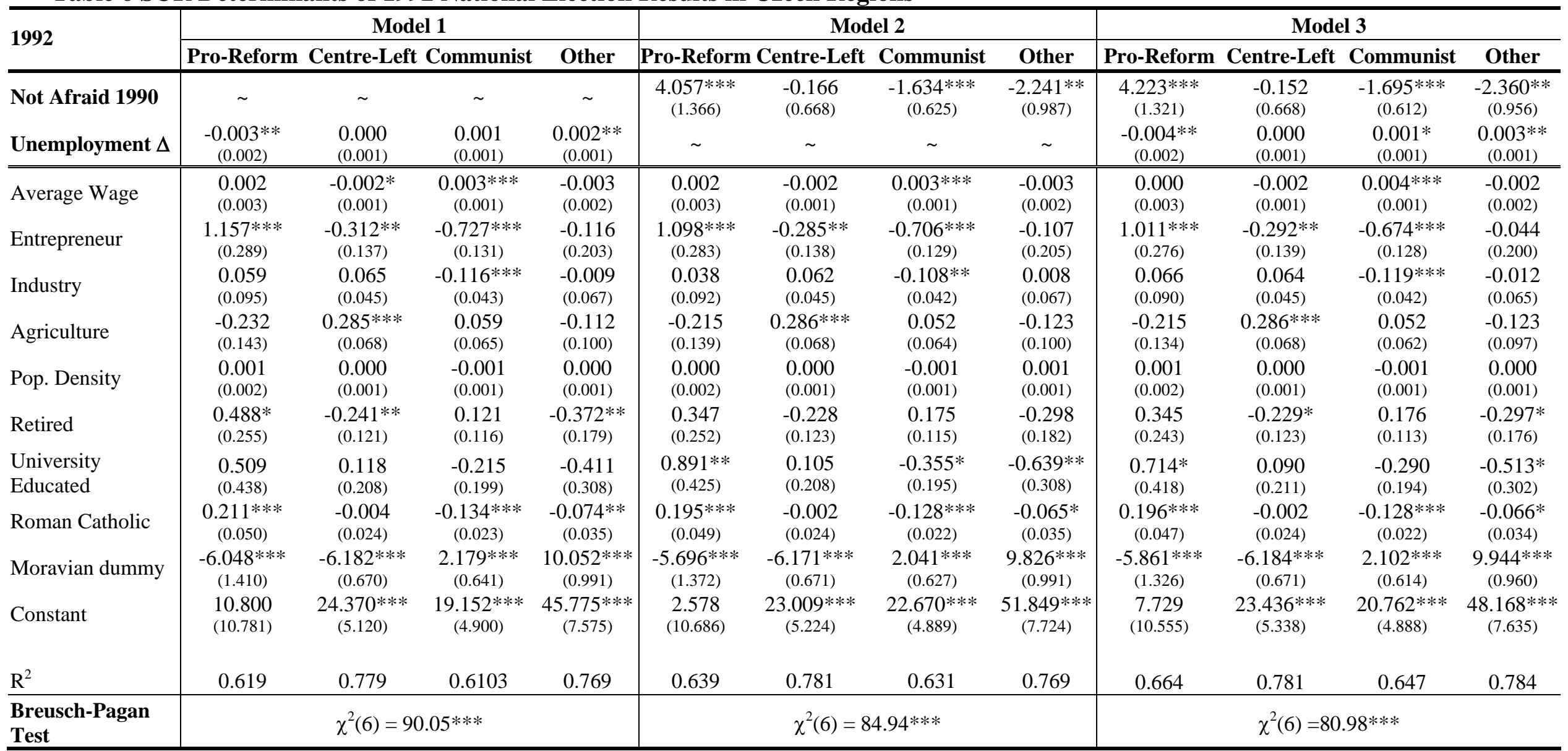

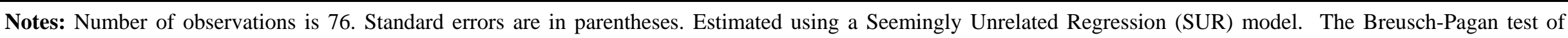

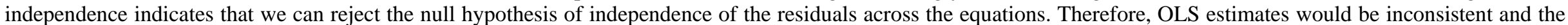
choice of SUR is justified. Significance levels are indicated as 1\% (***), 5\% (**) and 10\% (*). 
Table 7 SUR Determinants of 1996 National Election Results in Czech Regions

\begin{tabular}{|c|c|c|c|c|c|c|c|c|c|c|c|c|}
\hline \multirow{2}{*}{1996} & \multicolumn{4}{|c|}{ Model 1} & \multicolumn{4}{|c|}{ Model 2} & \multicolumn{4}{|c|}{ Model 3} \\
\hline & \multicolumn{3}{|c|}{ Pro-Reform Centre-Left Communist } & \multirow{2}{*}{$\begin{array}{c}\text { Other } \\
\sim\end{array}$} & \multirow{2}{*}{$\begin{array}{c}\text { Pro-Reform } \\
2.426^{*} \\
(1.251)\end{array}$} & \multirow{2}{*}{$\begin{array}{c}\text { Centre-Left } \\
-0.901 \\
(1.037)\end{array}$} & \multirow{2}{*}{$\begin{array}{c}\text { Communist } \\
-0.718 \\
(0.615)\end{array}$} & \multirow{2}{*}{$\begin{array}{c}\text { Other } \\
-0.824 \\
(0.715)\end{array}$} & \multicolumn{3}{|c|}{ Pro-Reform Centre-Left Communist } & \multirow{3}{*}{$\begin{array}{c}\text { Other } \\
-0.888 \\
(0.717) \\
0.002 \\
(0.003) \\
\end{array}$} \\
\hline Not Afraid 1990 & $\sim$ & $\sim$ & $\sim$ & & & & & & $\begin{array}{c}2.377^{*} \\
(1.260)\end{array}$ & $\begin{array}{l}-0.866 \\
(1.044)\end{array}$ & $\begin{array}{l}-0.643 \\
(0.615)\end{array}$ & \\
\hline Unemployment $\Delta$ & $\begin{array}{l}0.003 \\
(0.005) \\
\end{array}$ & $\begin{array}{r}-0.002 \\
(0.004) \\
\end{array}$ & $\begin{array}{r}-0.003 \\
(0.003) \\
\end{array}$ & $\begin{array}{l}0.002 \\
(0.003) \\
\end{array}$ & $\sim$ & $\sim$ & $\sim$ & $\sim$ & $\begin{array}{l}0.002 \\
(0.005) \\
\end{array}$ & $\begin{array}{r}-0.001 \\
(0.004) \\
\end{array}$ & $\begin{array}{l}-0.003 \\
(0.003) \\
\end{array}$ & \\
\hline Average Wage & $\begin{array}{l}0.001 \\
(0.002)\end{array}$ & $\begin{array}{l}-0.001 \\
(0.002)\end{array}$ & $\begin{array}{l}0.001 \\
(0.001)\end{array}$ & $\begin{array}{l}-0.001 \\
(0.001)\end{array}$ & $\begin{array}{l}0.000 \\
(0.002)\end{array}$ & $\begin{array}{l}-0.001 \\
(0.002)\end{array}$ & $\begin{array}{l}0.001 \\
(0.001)\end{array}$ & $\begin{array}{l}-0.001 \\
(0.001)\end{array}$ & $\begin{array}{l}0.001 \\
(0.002)\end{array}$ & $\begin{array}{l}-0.001 \\
(0.002)\end{array}$ & $\begin{array}{l}0.001 \\
(0.001)\end{array}$ & $\begin{array}{l}-0.001 \\
(0.001)\end{array}$ \\
\hline Entrepreneur & $\begin{array}{c}1.670 * * * \\
(0.346)\end{array}$ & $\begin{array}{c}-1.121 * * * \\
(0.282)\end{array}$ & $\begin{array}{c}-0.392 * * \\
(0.166)\end{array}$ & $\begin{array}{l}-0.147 \\
(0.194)\end{array}$ & $\begin{array}{c}1.463 * * * \\
(0.352)\end{array}$ & $\begin{array}{c}-1.032 * * * \\
(0.292)\end{array}$ & $\begin{array}{c}-0.325^{*} \\
(0.173)\end{array}$ & $\begin{array}{l}-0.095 \\
(0.201)\end{array}$ & $\begin{array}{c}1.476 * * * \\
(0.354)\end{array}$ & $\begin{array}{c}-1.042^{* * *} \\
(0.294)\end{array}$ & $\begin{array}{c}-0.345 * * \\
(0.173)\end{array}$ & $\begin{array}{l}-0.077 \\
(0.202)\end{array}$ \\
\hline Industry & $\begin{array}{c}0.220 * * * \\
(0.044)\end{array}$ & $\begin{array}{l}-0.023 \\
(0.036)\end{array}$ & $\begin{array}{c}-0.128 * * * \\
(0.021)\end{array}$ & $\begin{array}{c}-0.071 * * * \\
(0.025)\end{array}$ & $\begin{array}{c}0.205 * * * \\
(0.043)\end{array}$ & $\begin{array}{c}-0.016 \\
(0.036)\end{array}$ & $\begin{array}{c}-0.121^{* * *} \\
(0.021)\end{array}$ & $\begin{array}{c}-0.070 * * * \\
(0.025)\end{array}$ & $\begin{array}{c}0.207 * * * \\
(0.044)\end{array}$ & $\begin{array}{l}-0.018 \\
(0.036)\end{array}$ & $\begin{array}{c}-0.125^{* * *} \\
(0.021)\end{array}$ & $\begin{array}{c}-0.066^{* * *} \\
(0.025)\end{array}$ \\
\hline Agriculture & $\begin{array}{l}0.030 \\
(0.080)\end{array}$ & $\begin{array}{c}-0.072 \\
(0.065)\end{array}$ & $\begin{array}{c}0.098 * * \\
(0.039)\end{array}$ & $\begin{array}{c}-0.054 \\
(0.045)\end{array}$ & $\begin{array}{l}0.026 \\
(0.077)\end{array}$ & $\begin{array}{c}-0.070 \\
(0.064)\end{array}$ & $\begin{array}{c}0.107 * * * \\
(0.038)\end{array}$ & $\begin{array}{c}-0.061 \\
(0.044)\end{array}$ & $\begin{array}{l}0.032 \\
(0.079)\end{array}$ & $\begin{array}{c}-0.074 \\
(0.065)\end{array}$ & $\begin{array}{c}0.099 * * \\
(0.039)\end{array}$ & $\begin{array}{c}-0.054 \\
(0.045)\end{array}$ \\
\hline Pop. Density & $\begin{array}{l}0.000 \\
(0.002)\end{array}$ & $\begin{array}{l}0.000 \\
(0.001)\end{array}$ & $\begin{array}{l}-0.001 \\
(0.001)\end{array}$ & $\begin{array}{l}0.001 \\
(0.001)\end{array}$ & $\begin{array}{l}0.000 \\
(0.001)\end{array}$ & $\begin{array}{l}0.000 \\
(0.001)\end{array}$ & $\begin{array}{l}-0.001 \\
(0.001)\end{array}$ & $\begin{array}{l}0.001 \\
(0.001)\end{array}$ & $\begin{array}{l}0.000 \\
(0.001)\end{array}$ & $\begin{array}{l}0.000 \\
(0.001)\end{array}$ & $\begin{array}{c}-0.001 \\
(0.001)\end{array}$ & $\begin{array}{l}0.001 \\
(0.001)\end{array}$ \\
\hline Retired & $\begin{array}{c}0.430^{*} \\
(0.224)\end{array}$ & $\begin{array}{c}-0.467 * * \\
(0.183)\end{array}$ & $\begin{array}{l}0.018 \\
(0.108)\end{array}$ & $\begin{array}{l}0.020 \\
(0.126)\end{array}$ & $\begin{array}{c}0.376^{*} \\
(0.219)\end{array}$ & $\begin{array}{c}-0.442 * * \\
(0.182)\end{array}$ & $\begin{array}{l}0.045 \\
(0.108)\end{array}$ & $\begin{array}{l}0.022 \\
(0.125)\end{array}$ & $\begin{array}{c}0.386^{*} \\
(0.221)\end{array}$ & $\begin{array}{c}-0.450 * * \\
(0.184)\end{array}$ & $\begin{array}{l}0.029 \\
(0.108)\end{array}$ & $\begin{array}{l}0.036 \\
(0.126)\end{array}$ \\
\hline University Educated & $\begin{array}{c}0.990 * * * \\
(0.375)\end{array}$ & $\begin{array}{l}0.011 \\
(0.305)\end{array}$ & $\begin{array}{c}-0.397 * * \\
(0.180)\end{array}$ & $\begin{array}{c}-0.607 * * * \\
(0.210)\end{array}$ & $\begin{array}{c}1.148 * * * \\
(0.376)\end{array}$ & $\begin{array}{l}-0.062 \\
(0.312)\end{array}$ & $\begin{array}{c}-0.438 * * \\
(0.185)\end{array}$ & $\begin{array}{c}-0.653^{* * *} \\
(0.215)\end{array}$ & $\begin{array}{c}1.142 * * * \\
(0.377)\end{array}$ & $\begin{array}{l}-0.058 \\
(0.312)\end{array}$ & $\begin{array}{c}-0.429 * * \\
(0.184)\end{array}$ & $\begin{array}{c}-0.660 * * * \\
(0.214)\end{array}$ \\
\hline Roman Catholic & $\begin{array}{c}0.256 * * * \\
(0.044)\end{array}$ & $\begin{array}{c}-0.122 * * * \\
(0.036)\end{array}$ & $\begin{array}{c}-0.069 * * * \\
(0.021)\end{array}$ & $\begin{array}{c}-0.064 * * \\
(0.025)\end{array}$ & $\begin{array}{c}0.245 * * * \\
(0.043)\end{array}$ & $\begin{array}{c}-0.117 * * * \\
(0.036)\end{array}$ & $\begin{array}{c}-0.064 * * * \\
(0.021)\end{array}$ & $\begin{array}{c}-0.064^{* *} \\
(0.025)\end{array}$ & $\begin{array}{c}0.247 * * * \\
(0.044)\end{array}$ & $\begin{array}{c}-0.118 * * * \\
(0.036)\end{array}$ & $\begin{array}{c}-0.067 * * * \\
(0.021)\end{array}$ & $\begin{array}{c}-0.061 * * \\
(0.025)\end{array}$ \\
\hline Moravian dummy & $\begin{array}{c}-2.695^{*} \\
(1.404)\end{array}$ & $\begin{array}{c}3.058^{* * *} \\
(1.143)\end{array}$ & $\begin{array}{l}1.303^{*} \\
(0.674)\end{array}$ & $\begin{array}{c}-1.677 * * \\
(0.788)\end{array}$ & $\begin{array}{c}-2.792 * * \\
(1.373)\end{array}$ & $\begin{array}{c}3.104 * * * \\
(1.138)\end{array}$ & $\begin{array}{c}1.388^{* *} \\
(0.675)\end{array}$ & $\begin{array}{c}-1.711^{* *} \\
(0.784)\end{array}$ & $\begin{array}{c}-2.749 * * \\
(1.379)\end{array}$ & $\begin{array}{c}3.072 * * * \\
\quad(1.143)\end{array}$ & $\begin{array}{l}1.321^{*} \\
(0.674)\end{array}$ & $\begin{array}{c}-1.655^{* *} \\
(0.785)\end{array}$ \\
\hline Constant & $\begin{array}{c}-14.075 \\
(8.597)\end{array}$ & $\begin{array}{l}56.559 * * * \\
\quad(6.997)\end{array}$ & $\begin{array}{c}20.646 * * * \\
(4.126)\end{array}$ & $\begin{array}{c}36.352 * * * \\
(4.823)\end{array}$ & $\begin{array}{c}-15.160 * \\
(8.324)\end{array}$ & $\begin{array}{l}56.374 * * * \\
\quad(6.898)\end{array}$ & $\begin{array}{c}20.258 * * * \\
(4.092)\end{array}$ & $\begin{array}{c}38.038 * * * \\
(4.753)\end{array}$ & $\begin{array}{c}-15.863^{*} \\
(8.599)\end{array}$ & $\begin{array}{l}56.889 * * * \\
\quad(7.127)\end{array}$ & $\begin{array}{c}21.345 * * * \\
\quad(4.201)\end{array}$ & $\begin{array}{l}37.120 * * * \\
\quad(4.896)\end{array}$ \\
\hline $\mathrm{R}^{2}$ & 0.726 & 0.575 & 0.522 & 0.556 & 0.738 & 0.578 & 0.522 & 0.561 & 0.739 & 0.579 & 0.529 & 0.565 \\
\hline $\begin{array}{l}\text { Breusch-Pagan } \\
\text { Test }\end{array}$ & & $\chi^{2}(6)=$ & & & & $\chi^{2}(6)=$ & & & & & & \\
\hline
\end{tabular}

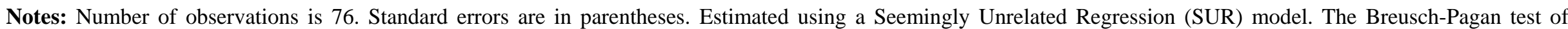

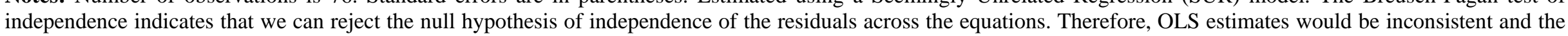
choice of SUR is justified. Significance levels are indicated as 1\% (***), 5\% (**) and 10\% (*). 
Table 8 SUR Determinants of 1998 National Election Results in Czech Regions

\begin{tabular}{|c|c|c|c|c|c|c|c|c|c|c|c|c|}
\hline \multirow[b]{2}{*}{1998} & \multicolumn{4}{|c|}{ Model 1} & \multicolumn{4}{|c|}{ Model 2} & \multicolumn{4}{|c|}{ Model 3} \\
\hline & Pro-Reform & Centre-Left & Communist & Other & $\begin{array}{c}\text { Pro- } \\
\text { Reform }\end{array}$ & Centre-Left & Communist & Other & $\begin{array}{c}\text { Pro- } \\
\text { Reform }\end{array}$ & Centre-Left & Communist & Other \\
\hline Not Afraid 1990 & $\sim$ & $\sim$ & $\sim$ & $\sim$ & $\begin{array}{c}3.474 * * * \\
(1.180)\end{array}$ & $\begin{array}{c}-2.167 * * \\
(0.976)\end{array}$ & $\begin{array}{c}-1.048 * \\
(0.566)\end{array}$ & $\begin{array}{l}-0.341 \\
(0.323)\end{array}$ & $\begin{array}{c}3.365^{* * *} \\
(1.172)\end{array}$ & $\begin{array}{c}-2.097 * * \\
(0.973)\end{array}$ & $\begin{array}{c}-1.038 * \\
(0.567)\end{array}$ & $\begin{array}{l}-0.316 \\
(0.322)\end{array}$ \\
\hline Unemployment $\Delta$ & $\begin{array}{l}0.013 \\
(0.008) \\
\end{array}$ & $\begin{array}{c}-0.008 \\
(0.006) \\
\end{array}$ & $\begin{array}{l}-0.001 \\
(0.004) \\
\end{array}$ & $\begin{array}{l}-0.003 \\
(0.002) \\
\end{array}$ & $\sim$ & $\sim$ & $\sim$ & $\sim$ & $\begin{array}{l}0.009 \\
(0.007) \\
\end{array}$ & $\begin{array}{c}-0.006 \\
(0.006) \\
\end{array}$ & $\begin{array}{l}-0.001 \\
(0.004) \\
\end{array}$ & $\begin{array}{l}-0.002 \\
(0.002) \\
\end{array}$ \\
\hline Average Wage & $\begin{array}{l}-0.002 \\
(0.001)\end{array}$ & $\begin{array}{l}0.001 \\
(0.001)\end{array}$ & $\begin{array}{c}0.001 * * \\
(0.001)\end{array}$ & $\begin{array}{c}-0.001 * * \\
(0.000)\end{array}$ & $\begin{array}{c}-0.002 * * \\
(0.001)\end{array}$ & $\begin{array}{l}0.002 \\
(0.001)\end{array}$ & $\begin{array}{c}0.001 * * * \\
(0.001)\end{array}$ & $\begin{array}{c}-0.001 * * \\
(0.000)\end{array}$ & $\begin{array}{c}-0.002 * \\
(0.001)\end{array}$ & $\begin{array}{l}0.001 \\
(0.001)\end{array}$ & $\begin{array}{c}0.001 * * \\
(0.001)\end{array}$ & $\begin{array}{c}-0.001 * * \\
(0.000)\end{array}$ \\
\hline Entrepreneur & $\begin{array}{c}0.459 * * \\
(0.179)\end{array}$ & $\begin{array}{c}-0.240 * \\
(0.144)\end{array}$ & $\begin{array}{c}-0.169 * * \\
(0.082)\end{array}$ & $\begin{array}{c}-0.048 \\
(0.048)\end{array}$ & $\begin{array}{c}0.587 * * * \\
(0.174)\end{array}$ & $\begin{array}{c}-0.327^{* *} \\
(0.144)\end{array}$ & $\begin{array}{c}-0.154^{*} \\
(0.083)\end{array}$ & $\begin{array}{c}-0.099 * * \\
(0.048)\end{array}$ & $\begin{array}{c}0.524 * * * \\
(0.180)\end{array}$ & $\begin{array}{c}-0.287^{*} \\
(0.149)\end{array}$ & $\begin{array}{c}-0.148^{*} \\
(0.087)\end{array}$ & $\begin{array}{c}-0.084 * \\
(0.049)\end{array}$ \\
\hline Industry & $\begin{array}{c}0.219 * * * \\
(0.066)\end{array}$ & $\begin{array}{c}-0.074 \\
(0.053)\end{array}$ & $\begin{array}{c}-0.132 * * * \\
(0.030)\end{array}$ & $\begin{array}{c}-0.012 \\
(0.018)\end{array}$ & $\begin{array}{c}0.208 * * * \\
(0.062)\end{array}$ & $\begin{array}{c}-0.067 \\
(0.051)\end{array}$ & $\begin{array}{c}-0.129 * * * \\
(0.030)\end{array}$ & $\begin{array}{l}-0.010 \\
(0.017)\end{array}$ & $\begin{array}{c}0.194 * * * \\
(0.062)\end{array}$ & $\begin{array}{c}-0.058 \\
(0.052)\end{array}$ & $\begin{array}{c}-0.127 * * * \\
(0.030)\end{array}$ & $\begin{array}{c}-0.007 \\
(0.017)\end{array}$ \\
\hline Agriculture & $\begin{array}{c}-0.240^{*} \\
(0.133)\end{array}$ & $\begin{array}{l}0.065 \\
(0.107)\end{array}$ & $\begin{array}{c}0.232 * * * \\
(0.061)\end{array}$ & $\begin{array}{l}-0.058 \\
(0.036)\end{array}$ & $\begin{array}{c}-0.134 \\
(0.124)\end{array}$ & $\begin{array}{l}-0.003 \\
(0.103)\end{array}$ & $\begin{array}{c}0.220 * * * \\
(0.060)\end{array}$ & $\begin{array}{c}-0.083 * * \\
(0.034)\end{array}$ & $\begin{array}{c}-0.170 \\
(0.127)\end{array}$ & $\begin{array}{l}0.020 \\
(0.105)\end{array}$ & $\begin{array}{c}0.223 * * * \\
(0.061)\end{array}$ & $\begin{array}{c}-0.075 * * \\
(0.035)\end{array}$ \\
\hline Pop. Density & $\begin{array}{c}-0.002 \\
(0.001)\end{array}$ & $\begin{array}{l}0.001 \\
(0.001)\end{array}$ & $\begin{array}{l}0.000 \\
(0.001)\end{array}$ & $\begin{array}{c}0.001 * * \\
(0.000)\end{array}$ & $\begin{array}{l}-0.001 \\
(0.001)\end{array}$ & $\begin{array}{l}0.001 \\
(0.001)\end{array}$ & $\begin{array}{l}0.000 \\
(0.001)\end{array}$ & $\begin{array}{c}0.001^{*} \\
(0.000)\end{array}$ & $\begin{array}{c}-0.002 \\
(0.001)\end{array}$ & $\begin{array}{l}0.001 \\
(0.001)\end{array}$ & $\begin{array}{l}0.000 \\
(0.001)\end{array}$ & $\begin{array}{c}0.001 * \\
(0.000)\end{array}$ \\
\hline Retired & $\begin{array}{c}0.780 * * * \\
(0.232)\end{array}$ & $\begin{array}{c}-0.520 * * * \\
(0.186)\end{array}$ & $\begin{array}{c}-0.183^{*} \\
(0.106)\end{array}$ & $\begin{array}{r}-0.082 \\
(0.062)\end{array}$ & $\begin{array}{c}0.639 * * * \\
(0.223)\end{array}$ & $\begin{array}{c}-0.432^{* *} \\
(0.184)\end{array}$ & $\begin{array}{c}-0.149 \\
(0.107)\end{array}$ & $\begin{array}{c}-0.059 \\
(0.061)\end{array}$ & $\begin{array}{c}0.638 * * * \\
(0.221)\end{array}$ & $\begin{array}{c}-0.432 * * \\
(0.183)\end{array}$ & $\begin{array}{c}-0.149 \\
(0.107)\end{array}$ & $\begin{array}{c}-0.059 \\
(0.061)\end{array}$ \\
\hline University Educated & $\begin{array}{c}1.576 * * * \\
(0.345)\end{array}$ & $\begin{array}{c}-0.617^{* *} \\
(0.278)\end{array}$ & $\begin{array}{c}-0.580 * * * \\
(0.158)\end{array}$ & $\begin{array}{c}-0.390 * * * \\
(0.093)\end{array}$ & $\begin{array}{c}1.773^{* * *} \\
(0.311)\end{array}$ & $\begin{array}{c}-0.739 * * * \\
(0.257)\end{array}$ & $\begin{array}{c}-0.621^{* * *} \\
(0.149)\end{array}$ & $\begin{array}{c}-0.422 * * * \\
(0.085)\end{array}$ & $\begin{array}{c}1.643 * * * \\
(0.326)\end{array}$ & $\begin{array}{c}-0.655^{* * *} \\
(0.270)\end{array}$ & $\begin{array}{c}-0.610 * * * \\
(0.158)\end{array}$ & $\begin{array}{c}-0.392 * * * \\
(0.089)\end{array}$ \\
\hline Roman Catholic & $\begin{array}{c}0.247 * * * \\
(0.046)\end{array}$ & $\begin{array}{c}-0.104 * * * \\
(0.037)\end{array}$ & $\begin{array}{c}-0.074 * * * \\
(0.021)\end{array}$ & $\begin{array}{c}-0.072 * * * \\
(0.012)\end{array}$ & $\begin{array}{c}0.215^{* * * *} \\
(0.044)\end{array}$ & $\begin{array}{c}-0.084 * * \\
(0.036)\end{array}$ & $\begin{array}{c}-0.071 * * * \\
(0.021)\end{array}$ & $\begin{array}{c}-0.064 * * * \\
(0.012)\end{array}$ & $\begin{array}{c}0.222 * * * \\
(0.044)\end{array}$ & $\begin{array}{c}-0.088 * * \\
(0.036)\end{array}$ & $\begin{array}{c}-0.072 * * * \\
(0.021)\end{array}$ & $\begin{array}{c}-0.065 * * * \\
(0.012)\end{array}$ \\
\hline Moravian dummy & $\begin{array}{c}-7.616^{* * * *} \\
(1.220)\end{array}$ & $\begin{array}{c}4.613 * * * \\
(0.980)\end{array}$ & $\begin{array}{c}2.711^{* * *} \\
(0.559)\end{array}$ & $\begin{array}{l}0.409 \\
(0.327)\end{array}$ & $\begin{array}{c}-6.918 * * * \\
(1.200)\end{array}$ & $\begin{array}{c}4.155^{* * * *} \\
(0.992)\end{array}$ & $\begin{array}{c}2.688 * * * \\
(0.575)\end{array}$ & $\begin{array}{l}0.186 \\
(0.328)\end{array}$ & $\begin{array}{c}-6.789 * * * \\
(1.192)\end{array}$ & $\begin{array}{c}4.072 * * * \\
(0.989)\end{array}$ & $\begin{array}{c}2.677 * * * \\
(0.577)\end{array}$ & $\begin{array}{l}0.156 \\
(0.327)\end{array}$ \\
\hline Constant & $\begin{array}{l}0.460 \\
(6.625)\end{array}$ & $\begin{array}{c}53.034 * * * \\
(5.323)\end{array}$ & $\begin{array}{c}22.965^{* * *} \\
(3.038)\end{array}$ & $\begin{array}{c}23.635 * * * \\
(1.777)\end{array}$ & $\begin{array}{l}-4.506 \\
(6.544)\end{array}$ & $\begin{array}{l}56.240^{* * *} \\
(5.409)\end{array}$ & $\begin{array}{c}24.595 * * * \\
(3.136)\end{array}$ & $\begin{array}{c}23.872^{* * *} \\
(1.791)\end{array}$ & $\begin{array}{l}-3.442 \\
(6.536)\end{array}$ & $\begin{array}{l}55.554 * * * \\
(5.424)\end{array}$ & $\begin{array}{c}24.503 * * * \\
(3.163)\end{array}$ & $\begin{array}{c}23.624^{* * *} \\
(1.793)\end{array}$ \\
\hline $\mathrm{R}^{2}$ & 0.747 & 0.566 & 0.645 & 0.710 & 0.768 & 0.580 & 0.657 & 0.725 & 0.773 & 0.585 & 0.657 & 0.729 \\
\hline $\begin{array}{l}\text { Breusch-Pagan } \\
\text { Test }\end{array}$ & \multicolumn{4}{|c|}{$\chi^{2}(6)=83.87^{* * *}$} & \multicolumn{4}{|c|}{$\chi^{2}(6)=75.16^{* * *}$} & \multicolumn{4}{|c|}{$\chi^{2}(6)=74.27^{* * *}$} \\
\hline
\end{tabular}

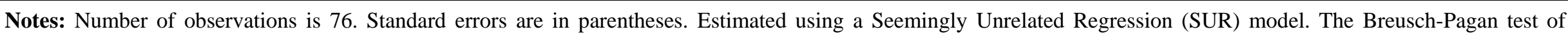

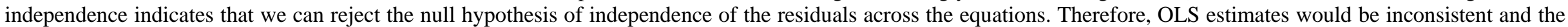
choice of SUR is justified. Significance levels are indicated as $1 \%(* * *), 5 \%(* *)$ and $10 \%(*)$. 
Table 9 SUR Determinants of 2002 National Election Results in Czech Regions

\begin{tabular}{|c|c|c|c|c|c|c|c|c|c|c|c|c|}
\hline \multirow{2}{*}{2002} & \multicolumn{4}{|c|}{ Model 1} & \multicolumn{4}{|c|}{ Model 2} & \multicolumn{4}{|c|}{ Model 3} \\
\hline & Pro-Reform & Centre-Left & Communist & Other & Pro-Reform & Centre-Left & Communist & Other & Pro-Reform & Centre-Left & Communist & Other \\
\hline Not Afraid 1990 & $\sim$ & $\sim$ & $\sim$ & $\sim$ & $\begin{array}{c}3.033 * * * \\
(1.109)\end{array}$ & $\begin{array}{c}-1.632 * \\
(0.923)\end{array}$ & $\begin{array}{c}-2.285 * * * \\
(0.863)\end{array}$ & $\begin{array}{c}0.888 * \\
(0.478)\end{array}$ & $\begin{array}{c}3.358 * * * \\
(1.020)\end{array}$ & $\begin{array}{c}-1.836 * * \\
(0.883)\end{array}$ & $\begin{array}{c}-2.457 * * * \\
(0.834)\end{array}$ & $\begin{array}{c}0.938 * * \\
(0.475)\end{array}$ \\
\hline Unemployment $\Delta$ & $\begin{array}{c}0.054^{* * * *} \\
(0.017) \\
\end{array}$ & $\begin{array}{c}-0.034^{* *} \\
(0.014) \\
\end{array}$ & $\begin{array}{c}-0.028^{* *} \\
(0.014) \\
\end{array}$ & $\begin{array}{l}0.008 \\
(0.008) \\
\end{array}$ & $\sim$ & $\sim$ & $\sim$ & $\sim$ & $\begin{array}{c}0.061^{* * *} \\
(0.016) \\
\end{array}$ & $\begin{array}{c}-0.038 * * * \\
(0.014) \\
\end{array}$ & $\begin{array}{c}-0.032 * * \\
(0.013) \\
\end{array}$ & $\begin{array}{l}0.009 \\
(0.008) \\
\end{array}$ \\
\hline Average Wage & $\begin{array}{c}0.002 * \\
(0.001)\end{array}$ & $\begin{array}{l}0.001 \\
(0.001)\end{array}$ & $\begin{array}{l}-0.001 \\
(0.001)\end{array}$ & $\begin{array}{c}-0.002 * * * \\
(0.001)\end{array}$ & $\begin{array}{l}0.002 \\
(0.002)\end{array}$ & $\begin{array}{l}0.001 \\
(0.001)\end{array}$ & $\begin{array}{l}-0.001 \\
(0.001)\end{array}$ & $\begin{array}{c}-0.003 * * * \\
(0.001)\end{array}$ & $\begin{array}{l}0.001 \\
(0.001)\end{array}$ & $\begin{array}{l}0.002 \\
(0.001)\end{array}$ & $\begin{array}{l}0.000 \\
(0.001)\end{array}$ & $\begin{array}{c}-0.003 * * * \\
(0.001)\end{array}$ \\
\hline Entrepreneur & $\begin{array}{c}0.657 * * * \\
(0.200)\end{array}$ & $\begin{array}{c}-0.385^{* *} \\
(0.167)\end{array}$ & $\begin{array}{c}-0.317 * * \\
(0.159)\end{array}$ & $\begin{array}{l}0.045 \\
(0.088)\end{array}$ & $\begin{array}{c}0.850 * * * \\
(0.222)\end{array}$ & $\begin{array}{c}-0.551^{* * *} \\
(0.185)\end{array}$ & $\begin{array}{c}-0.353 * * \\
(0.173)\end{array}$ & $\begin{array}{l}0.054 \\
(0.096)\end{array}$ & $\begin{array}{c}0.674^{* * *} \\
(0.208)\end{array}$ & $\begin{array}{c}-0.440 * * \\
(0.181)\end{array}$ & $\begin{array}{l}-0.260 \\
(0.170)\end{array}$ & $\begin{array}{l}0.027 \\
(0.097)\end{array}$ \\
\hline Industry & $\begin{array}{c}0.114^{* * *} \\
(0.040)\end{array}$ & $\begin{array}{c}-0.027 \\
(0.033)\end{array}$ & $\begin{array}{c}-0.167 * * * \\
(0.032)\end{array}$ & $\begin{array}{c}0.080 * * * \\
(0.017)\end{array}$ & $\begin{array}{c}0.090 * * \\
(0.042)\end{array}$ & $\begin{array}{c}-0.009 \\
(0.035)\end{array}$ & $\begin{array}{c}-0.157 * * * \\
(0.032)\end{array}$ & $\begin{array}{c}0.076^{* * *} * \\
(0.018)\end{array}$ & $\begin{array}{c}0.094 * * \\
(0.038)\end{array}$ & $\begin{array}{c}-0.011 \\
(0.033)\end{array}$ & $\begin{array}{c}-0.159 * * * \\
(0.031)\end{array}$ & $\begin{array}{c}0.077 * * * \\
(0.018)\end{array}$ \\
\hline Agriculture & $\begin{array}{c}0.398 * * \\
(0.154)\end{array}$ & $\begin{array}{c}-0.412^{* * * *} \\
(0.128)\end{array}$ & $\begin{array}{c}-0.147 \\
(0.123)\end{array}$ & $\begin{array}{c}0.161^{* *} \\
(0.068)\end{array}$ & $\begin{array}{c}0.340 * * \\
(0.158)\end{array}$ & $\begin{array}{c}-0.391 * * * \\
(0.131)\end{array}$ & $\begin{array}{c}-0.101 \\
(0.123)\end{array}$ & $\begin{array}{c}0.152^{* *} \\
(0.068)\end{array}$ & $\begin{array}{c}0.439 * * * \\
(0.147)\end{array}$ & $\begin{array}{c}-0.453^{* * * *} \\
(0.127)\end{array}$ & $\begin{array}{c}-0.153 \\
(0.120)\end{array}$ & $\begin{array}{c}0.167 * * \\
(0.068)\end{array}$ \\
\hline Pop. Density & $\begin{array}{c}-0.004 * * * \\
(0.002)\end{array}$ & $\begin{array}{l}0.002 \\
(0.001)\end{array}$ & $\begin{array}{c}0.003^{* *} \\
(0.001)\end{array}$ & $\begin{array}{l}-0.001 \\
(0.001)\end{array}$ & $\begin{array}{c}-0.003 * \\
(0.002)\end{array}$ & $\begin{array}{l}0.001 \\
(0.001)\end{array}$ & $\begin{array}{c}0.002 * \\
(0.001)\end{array}$ & $\begin{array}{r}-0.001 \\
(0.001)\end{array}$ & $\begin{array}{c}-0.004^{* *} \\
(0.001)\end{array}$ & $\begin{array}{l}0.002 \\
(0.001)\end{array}$ & $\begin{array}{c}0.003^{* *} \\
(0.001)\end{array}$ & $\begin{array}{r}-0.001 \\
(0.001)\end{array}$ \\
\hline Retired & $\begin{array}{c}0.632 * * \\
(0.320)\end{array}$ & $\begin{array}{l}0.308 \\
(0.266)\end{array}$ & $\begin{array}{c}-0.611^{* *} \\
(0.255)\end{array}$ & $\begin{array}{c}-0.331 * * \\
(0.141)\end{array}$ & $\begin{array}{l}0.378 \\
(0.327)\end{array}$ & $\begin{array}{c}0.461^{*} \\
(0.272)\end{array}$ & $\begin{array}{c}-0.456^{*} \\
(0.255)\end{array}$ & $\begin{array}{c}-0.384 * * * \\
(0.141)\end{array}$ & $\begin{array}{l}0.475 \\
(0.301)\end{array}$ & $\begin{array}{l}0.400 \\
(0.261)\end{array}$ & $\begin{array}{c}-0.508^{* *} \\
(0.246)\end{array}$ & $\begin{array}{c}-0.369 * * * \\
(0.140)\end{array}$ \\
\hline Roman Catholic & $\begin{array}{c}0.103^{* *} \\
(0.042)\end{array}$ & $\begin{array}{l}0.051 \\
(0.035)\end{array}$ & $\begin{array}{c}-0.112^{* * *} \\
(0.033)\end{array}$ & $\begin{array}{c}-0.043 * * \\
(0.018)\end{array}$ & $\begin{array}{c}0.112 * * * \\
(0.042)\end{array}$ & $\begin{array}{l}0.047 \\
(0.035)\end{array}$ & $\begin{array}{c}-0.115^{* * * *} \\
(0.033)\end{array}$ & $\begin{array}{c}-0.043^{* *} \\
(0.018)\end{array}$ & $\begin{array}{c}0.088^{* *} \\
(0.039)\end{array}$ & $\begin{array}{c}0.061^{*} \\
(0.034)\end{array}$ & $\begin{array}{c}-0.103^{* * *} \\
(0.032)\end{array}$ & $\begin{array}{c}-0.046 * * \\
(0.018)\end{array}$ \\
\hline Moravian dummy & $\begin{array}{c}-3.772 * * * \\
(1.088)\end{array}$ & $\begin{array}{l}1.456 \\
(0.905)\end{array}$ & $\begin{array}{c}3.063 * * * \\
(0.865)\end{array}$ & $\begin{array}{r}-0.752 \\
(0.478)\end{array}$ & $\begin{array}{c}-2.752^{* *} \\
(1.145)\end{array}$ & $\begin{array}{l}0.672 \\
(0.953)\end{array}$ & $\begin{array}{c}2.708 * * * \\
(0.891)\end{array}$ & $\begin{array}{c}-0.632 \\
(0.494)\end{array}$ & $\begin{array}{c}-3.402 * * * \\
(1.063)\end{array}$ & $\begin{array}{l}1.079 \\
(0.921)\end{array}$ & $\begin{array}{c}3.051 * * * \\
(0.869)\end{array}$ & $\begin{array}{l}-0.733 \\
(0.495)\end{array}$ \\
\hline Constant & $\begin{array}{c}-12.566^{*} \\
(7.622)\end{array}$ & $\begin{array}{l}33.452 * * * \\
(6.341)\end{array}$ & $\begin{array}{l}59.497 * * * \\
(6.063)\end{array}$ & $\begin{array}{c}19.642 * * * \\
(3.346)\end{array}$ & $\begin{array}{c}-14.918^{*} \\
(7.912)\end{array}$ & $\begin{array}{l}35.168 * * * \\
(6.586)\end{array}$ & $\begin{array}{c}61.006 * * * \\
(6.157)\end{array}$ & $\begin{array}{c}18.767 * * * \\
(3.410)\end{array}$ & $\begin{array}{c}-14.199 * \\
(7.250)\end{array}$ & $\begin{array}{c}34.718^{* * * *} \\
(6.280)\end{array}$ & $\begin{array}{c}60.626 * * * \\
(5.927)\end{array}$ & $\begin{array}{c}18.879 * * * \\
\quad(3.376)\end{array}$ \\
\hline $\mathrm{R}^{2}$ & 0.700 & 0.358 & 0.700 & 0.447 & 0.693 & 0.354 & 0.704 & 0.463 & 0.742 & 0.413 & 0.726 & 0.474 \\
\hline $\begin{array}{l}\text { Breusch-Pagan } \\
\text { Test }\end{array}$ & \multicolumn{4}{|c|}{$\chi^{2}(6)=106.7^{* * *}$} & \multicolumn{4}{|c|}{$\chi^{2}(6)=101.07^{* * *}$} & \multicolumn{4}{|c|}{$\chi^{2}(6)=90.2^{* * *}$} \\
\hline
\end{tabular}

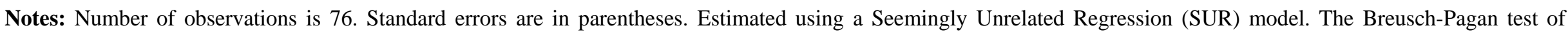

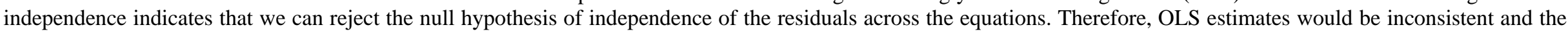
choice of SUR is justified. Significance levels are indicated as $1 \%\left(^{* * *}\right), 5 \%\left(^{* *}\right)$ and $10 \%\left(^{*}\right)$. 
Table 10 Modelling the 1990 Election

\begin{tabular}{l|ccc|ccc}
\hline & \multicolumn{3}{|c|}{ Model 1 } & \multicolumn{3}{c}{ Model 2 } \\
& Pro-Reform & Communist & Other & Pro-Reform & Communist & Other \\
Unemployment 1990 & $\sim$ & $\sim$ & $\sim$ & 0.925 & 1.030 & -2.108 \\
& & & & $(1.806)$ & $(0.760)$ & $(1.420)$ \\
Unemployment 2002 & $-0.568^{* * *}$ & $0.142^{*}$ & $0.438^{* * *}$ & $-0.590^{* * *}$ & 0.118 & $0.488^{* * *}$ \\
& $(0.181)$ & $(0.077)$ & $(0.144)$ & $(0.186)$ & $(0.078)$ & $(0.146)$ \\
$\mathrm{R}^{2}$ & 0.578 & 0.331 & 0.698 & 0.580 & 0.347 & 0.707 \\
\hline Breusch-Pagan Test & \multicolumn{3}{|c|}{$\chi^{2}(6)=96.04 * * *$} \\
\hline
\end{tabular}

Notes: Number of observations is 76. Standard errors are in parentheses. Each model is estimated using a Seemingly Unrelated Regression (SUR) model. Average wage, population density, retired, university education, Roman Catholic and Moravian dummy variables are also included but not reported. The Breusch-Pagan test of independence indicates that we can reject the null hypothesis of independence of the residuals across the equations. Therefore, OLS estimates would be inconsistent and the choice of SUR is justified. Significance levels are indicated as $1 \%(* * *), 5 \%(* *)$ and $10 \% .(*)$. 
Table 11 Effect of Future Unemployment Rates on 1990 Vote Choice

\begin{tabular}{|c|c|c|c|c|c|c|c|c|c|c|c|c|}
\hline \multirow{2}{*}{1990 Election } & \multicolumn{3}{|c|}{ Model 1} & \multicolumn{3}{|c|}{ Model 2} & \multicolumn{3}{|c|}{ Model 3} & \multicolumn{3}{|c|}{ Model 4} \\
\hline & Pro-Reform & Communist & Other & Pro-Reforn & Communist & Other & Pro-Reform & Communist & Other & Pro-Reform & Communist & Other \\
\hline $\begin{array}{l}\text { Unemployment } \\
1992\end{array}$ & $\begin{array}{l}-1.465^{* * *} \\
(0.477)\end{array}$ & $\begin{array}{c}0.785 * * * \\
(0.186)\end{array}$ & $\begin{array}{l}0.644 \\
(0.394)\end{array}$ & & & & $\sim$ & $\sim$ & $\sim$ & $\sim$ & $\sim$ & $\sim$ \\
\hline $\begin{array}{l}\text { Unemployment } \\
1996\end{array}$ & $\sim$ & $\sim$ & $\sim$ & $\begin{array}{c}-1.146^{* * *} \\
(0.367)\end{array}$ & $\begin{array}{c}0.507 * * * \\
(0.149)\end{array}$ & $\begin{array}{c}0.645^{* *} \\
(0.300)\end{array}$ & $\sim$ & $\sim$ & $\sim$ & $\sim$ & $\sim$ & $\sim$ \\
\hline $\begin{array}{l}\text { Unemployment } \\
1998\end{array}$ & $\sim$ & $\sim$ & $\sim$ & $\sim$ & $\sim$ & $\sim$ & $\begin{array}{c}-0.772 * * * \\
(0.225)\end{array}$ & $\begin{array}{c}0.297 * * * \\
(0.093)\end{array}$ & $\begin{array}{c}0.483 * * * \\
(0.183)\end{array}$ & $\sim$ & $\sim$ & $\sim$ \\
\hline $\begin{array}{l}\text { Unemployment } \\
2002\end{array}$ & $\sim$ & $\sim$ & $\sim$ & $\sim$ & $\sim$ & $\sim$ & $\sim$ & $\sim$ & $\sim$ & $\begin{array}{c}-0.568 * * * \\
(0.181)\end{array}$ & $\begin{array}{c}0.142^{*} \\
(0.077)\end{array}$ & $\begin{array}{c}0.438 * * * \\
(0.144)\end{array}$ \\
\hline$\overline{\mathrm{R}^{2}}$ & 0.576 & 0.433 & 0.673 & 0.578 & 0.394 & 0.681 & 0.588 & 0.384 & 0.690 & 0.578 & 0.331 & 0.698 \\
\hline
\end{tabular}

Notes: Number of observations is 76. Standard errors are in parentheses. Estimated using a Seemingly Unrelated Regression (SUR) model. Average wage, population density, retired, university education, Roman Catholic and Moravian dummy variables are also included but not reported. Significance levels are indicated as $1 \%$ (***), 5\% (**) and $10 \%$ (*). 